\title{
HUBUNGAN ANTARA KONDISI TAJUK Eucalyptus pellita F. Muell DENGAN INFEKSI PENYAKIT BUSUK AKAR
}

\author{
Correlation between Crown Condition of Eucalyptus pellita F. Muell \\ and Root rot Infection
}

\author{
Luciasih Agustini dan/and Ragil SB Irianto \\ Pusat Penelitian dan Pengembangan Hutan
}

Jl. Gunung Batu No. 5 PO BOX 165, Bogor 16610 Jawa Barat, Indonesia

Tlp. (0251) 8633234; 7520067 Fax. (0251) 8638111

Email: luci_agustini@forda-mof.org,ragil.irianto@gmail.com

Tanggal diterima: 21 April 2015; Tanggal direvisi: 18 Mei 2016; Tanggal disetujui: 6 Juni 2016

\begin{abstract}
Functional disruption of cells and tissues within individual leaves due to pests and diseases infection subsequently causes in deterioration of crown, canopy contraction, and even tree death. Crown condition usually used as visual indicator for tree health assessment. Root-rot is considered as the most damaging disease for Eucalyptus pellita plantations. Methodology for the detection of rootrot at an early stage is required. In order to develop root rot detection method, this study investigates relationship between crown symptoms and root rot disease in E. pellita plantation. A visual assessment method to classify the crown condition of trees in plantations of $\underline{E}$. pellita was developed. Repeatability, reproducibility and reliability of the developed method were examined by conducting repeated surveys. Applicability of the method to indicate root-rot incidence and severity at individual tree level was tested in seven plots. At the plot level, the crown-conditions were significantly correlated with the incidence and severity of root rot. At the tree level, the crown conditions were not significantly correlated with root-rot incidence and severity. Probability of these crown-indicators for estimating root-rot incidence and severity in individual tree is $61.4 \%$ and $41.6 \%$, respectively. In order to prevent risks of massive productivity loss, root-rot site risk assessments are suggested to be conducted before plantation expansion.
\end{abstract}

\section{Keywords: Crown condition, Eucalyptus pellita, incidence, root rot, severity}

\begin{abstract}
ABSTRAK
Gangguan fungsional pada sel-sel dan jaringan daun akibat serangan hama dan penyakit dapat menyebabkan perubahan pada tajuk, penyusutan kanopi dan bahkan dapat menyebabkan kematian pohon. Kondisi tajuk merupakan indikator visual untuk menilai kesehatan suatu pohon. Penyakit busuk akar merupakan salah satu penyakit yang mengancam produktivitas tegakan E. pellita dan sampai saat ini belum dapat dikendalikan dengan efektif. Metode pendeteksian penyakit busuk akar melalui pengamatan karakteritik kondisi tajuk menjadi penting untuk diketahui. Penelitian ini bertujuan mengembangkan metode penilaian kondisi tajuk guna mengetahui hubungan antara kondisi tajuk dengan keberadaan dan tingkat keparahan penyakit busuk akar pada tegakan $E$. pellita. Penelitian diawali dengan mengklasifikasikan kondisi tajuk E. pellita ke dalam 5 kelas. Metode klasifikasi ini diuji repeatability, reproducibility dan reliability. Penerapan metode penilaian kondisi tajuk dalam menduga keberadaan dan level keparahan penyakit busuk akar diuji pada 7 plot pengamatan. Hasil penelitian menunjukkan bahwa pada level plot, kondisi tajuk E. pellita secara signifikan berkorelasi dengan serangan penyakit busuk akar. Namun, pada level individu pohon masih sulit dideteksi. Peluang kondisi tajuk E. pellita dalam menduga keberadaan penyakit busuk akar sebesar $61,4 \%$ dan tingkat keparahan sebesar $41,6 \%$. Penilaian potensi suatu kawasan terhadap serangan penyakit busuk akar perlu dilakukan sebelum pembukaan hutan tanaman industri agar kerugian besar akibat penyakit busuk akar dapat dihindari.
\end{abstract}

Kata kunci: Eucalyptus pellita, keberadaan, kondisi tajuk, penyakit busuk akar, tingkat keparahan 


\section{PENDAHULUAN}

Kondisi tajuk sebuah tanaman berkaitan langsung dengan produktivitas tanaman, karena pada bagian tajuk terjadi proses fotosintesis yang mengubah energi matahari menjadi substrat yang diperlukan tanaman untuk tumbuh dan berkembang (Schomaker et al., 2007). Kondisi tajuk merupakan parameter yang umum digunakan sebagai indikator kesehatan tanaman (Stone \& Haywood, 2006). Kondisi tajuk adalah manifestasi dari kondisi fisiologis dan morfologis daundaun penyusunnya. Gangguan fungsional pada sel-sel dan jaringan daun, baik sebagai respons terhadap cekaman lingkungan maupun serangan hama dan penyakit, pada intensitas gangguan tertentu akan menyebabkan perubahan pada tajuk, penyusutan kanopi bahkan pada level yang lebih parah dapat mengakibatkan kematian pohon dan menimbulkan ruang kosong (gaps) pada populasi tegakan pohon tersebut (Cunningham et al., 2007; Horton et al., 2011).

Banyak penelitian telah melakukan studi untuk mengetahui respon tajuk pohon terhadap pengaruh cekaman lingkungan, hama dan penyakit (Bakys et al., 2011; Carnicer et al., 2011; Pautasso et al., 2015; Vollenweider dan Gunthardt-Goerg, 2006; Wang et al., 2007; Wolken et al., 2009). Pada umumnya pengamatan kondisi tajuk dihubungkan dengan serangan penyakit yang menyerang daun, seperti mati pucuk (shoot blight) yang disebabkan oleh fungi Quambalaria sp. dan bercak daun (leaf spot) yang disebabkan oleh Mycosphaerella sp. yang menyerang tegakan Eucalyptus spp. dan Corymbia spp. (Carnegie, 2007). Adanya gejala klorosis dan jaringan nekrotik pada tajuk yang diamati, mengindikasikan adanya serangan patogen yang menyerang daun-daun tersebut. Hanya beberapa saja yang meneliti kaitan antara kondisi tajuk dengan cekaman pada perakaran, terutama yang disebabkan oleh penyakit busuk akar dan menunjukkan hasil yang bervariasi (Carnicer et al., 2011; Francis et al., 2014). Padahal patogen akar yang menyerang jaringan pembuluh tanaman inang secara tidak langsung dapat mempengaruhi proses fotosintesis daun yang secara kumulatif dapat diamati pada kondisi tajuk (Agustini et al., 2015; Berger et al., 2007; Morin etal., 2015).

Penyakit busuk akar merupakan penyakit yang paling merusak, intensitas serangannya terus bertambah seiring dengan umur dan rotasi tanaman. Di Malaysia tercatat bahwa kematian pohon Acacia mangium Willd umur 14 tahun karena serangan penyakit busuk akar mencapai $40 \%$ (Glen et al., 2009) Di Filipina, tercatat antara $10-25 \%$ pohon mati akibat busuk akar pada tegakan umur 6-10 tahun (Eyles et al., 2008). Di Indonesia, sekitar 3-28\% tegakan A. mangium umur 3-5 tahun dilaporkan telah terserang penyakit busuk akar (Irianto, et al., 2006). Besarnya persentase serangan busuk akar pada suatu lokasi, apalagi sampai mengakibatkan kematian pohon, tentu saja berdampak pada menurunnya produktivitas dan kerugian secara finansial.

Eucalyptus pellita $\mathrm{F}$. Muell. merupakan salah satu tanaman yang digunakan sebagai bahan baku bagi industri pulp dan kertas di Indonesia. Jenis ekaliptus ini merupakan salah satu pilihan selain $A$. mangium yang telah mejadi komoditas utama Hutan Tanaman Industri (HTI) di Indonesia. E. pellita memiliki pertumbuhan yang lebih baik (Sulichantini, 2016) dan lebih tahan terhadap penyakit daun dibandingkan jenis ekaliptus lain (Agustini et al., 2013). Namun berdasarkan studi di beberapa lokasi HTI di Riau, Sumatera Selatan dan Kalimantan Timur, ternyata baik $A$. mangium maupun E. pellita rentan terhadap serangan penyakit busuk akar (Agustini et al., 2014; Francis et al., 2014; Eyles et al., 2008; Irianto et al., 2006).

Mengenali gejala-gejala yang tampak pada tanaman merupakan salah satu aspek yang penting dalam upaya mengendalikan suatu penyakit tanaman. Untuk mengenali penyakit busuk akar biasanya dilakukan observasi perakaran dengan cara menggali tanah di sekitar perakaran tersebut. Brazee \& Wick (2009) menggunakan gejala mati pucuk (crown dieback), daun yang klorosis dan ukuran lebih kecil sebagai indikator pohon yang terinfeksi Armillaria spp. di hutan campuran di Massachusetts, USA, selain gejala-gejala yang tampak pada pangkal batang, seperti basal cavities, basal resinosis. Francis et al. (2014) menggunakan gejala yang tampak pada tajuk $A$. mangium, yaitu: menguningnya daun (discolorisation) dan kerapatan tajuk sebagai indikator mengamati pola penyebaran busuk akar yang disebabkan oleh patogen Ganoderma philippii. Sampai saat ini, belum ada publikasi yang melaporkan hubungan antara serangan penyakit busuk akar terhadap kondisi tajuk E. pellita. Tujuan penelitian adalah mengembangkan metode penilaian kondisi tajuk E. pellita guna mengetahui hubungan antara kondisi tajuk dengan keberadaan (incidence) dan tingkat keparahan (severity) penyakit busuk akar pada tegakan E. pellita di salah satu lokasi HTI di Riau. 


\section{METODOLOGI}

\section{A. Waktu dan Lokasi Penelitian}

Survey dilakukan 3 kali, yaitu pada bulan Juni 2008 (survey I), Oktober 2008 (survey II) dan Februari 2009 (survey III) di 7 plot tegakan $E$. pellita yang tersebar di 3 lokasi (Tabel 1) di Riau. Seluruh lokasi yang dipilih sebagai plot pengamatan merupakan lokasi yang terserang penyakit busuk akar.

\section{B. Pengamatan Kondisi Tajuk E. pellita}

Kondisi tajuk E. pellita diamati secara visual dalam 2 tahap pengamatan, yaitu: (1) kesan kondisi kesehatan pohon secara umum, berdasarkan kriteria yang tercantum pada Tabel 2 dan (2) pengamatan/pengukuran indikator tajuk yang lebih terperinci. Kriteria kesehatan pohon dibuat berdasarkan pengamatan deskriptif terhadap variasi kondisi tajuk E. pellita pada survey pendahuluan di 12 kompartemen. Variasi kondisi tajuk lalu dikelompokkan menjadi 6 kelas, mulai dari kondisi tajuk yang mati sampai dengan sangat sehat (Tabel 2, Gambar 1). Adapun indikator tajuk E. pellita diamati secara lebih terperinci adalah:

1. Dominansi tajuk (tajuk ditentukan pada salah satu dari tiga kategori berikut, yaitu: Dominant, Sub-dominant (Co-dominant dan Suppressed).

2. Tinggi pohon (m), diukur menggunakan hypsometer.

3. Diameter pohon setinggi dada $(\mathrm{DBH})(\mathrm{cm})$.

4. Rasio tajuk-hidup (live crown ratio) yang ditentukan dari proporsi tinggi tajuk (diukur dari pucuk tajuk sampai dahan berdaun yang paling bawah) terhadap total tinggi pohon $(\%)$.

5. Kerapatan tajuk (crown density) ditentukan dengan membandingkan kerapatan tajuk pohon yang diukur dengan pohon yang paling rapat tajuknya di plot tersebut (\%).

6. Daun tua dan daun muda pada tajuk setiap pohon $(\%)$.

Proporsi warna pada tajuk yang terdiri dari persentase warna hijau, kuning kehijauan dan kuning $(\%)$.

Sebelum digunakan untuk menduga keberadaan (incidence) dan level keparahan (severity) penyakit busuk akar pada tegakan E. pellita, metode penilaian tajuk ini diuji repeatability, reproducibility dan reliability-nya. Repeatability didefinisikan sebagai kemampuan metode ini untuk diulang oleh asesor yang sama pada waktu yang berbeda sedangkan reproducibility adalah kemampuan metode ini untuk diulang asesor yang berbeda, yang bekerja secara independen, pada waktu yang sama, dengan level error yang masih dapat diterima secara statistik (Smith et al., 2007). Repeatability dan reproducibility metode ini diujikan pada 20 pohon di suatu area oleh 3 orang asesor yang bekerja secara independen. Pengamatan dilakukan 2 kali pada hari yang sama, yaitu pagi hari (pukul 9.00-10.00) dan sore hari (pukul 14.00-15.00). Adapun reliability didefinisikan sebagai kemampuan suatu metode/ alat/sistem tertentu dalam menjalankan fungsinya, memberikan hasil yang konsisten (Bartlett \& Frost, 2008). Dalam studi ini, reliability ditentukan dari konsistensi indikator-indikator tajuk dalam mengelompokkan E. pellita pada kelas tertentu. Reliability diuji dengan melakukan survey ulangan, yaitu survey II dan III.

\section{Pengamatan Kondisi Perakaran}

Pengukuran intensitas infeksi akar dilakukan dengan cara menggali sistem perakaran dalam radius $50 \mathrm{~cm}$ dari pangkal batang dengan kedalaman sekitar $30 \mathrm{~cm}$. Akar lateral yang digali kemudian dihitung persentase infeksinya. Per-

Tabel (Table) 1. Lokasi penelitian (Studied sites)

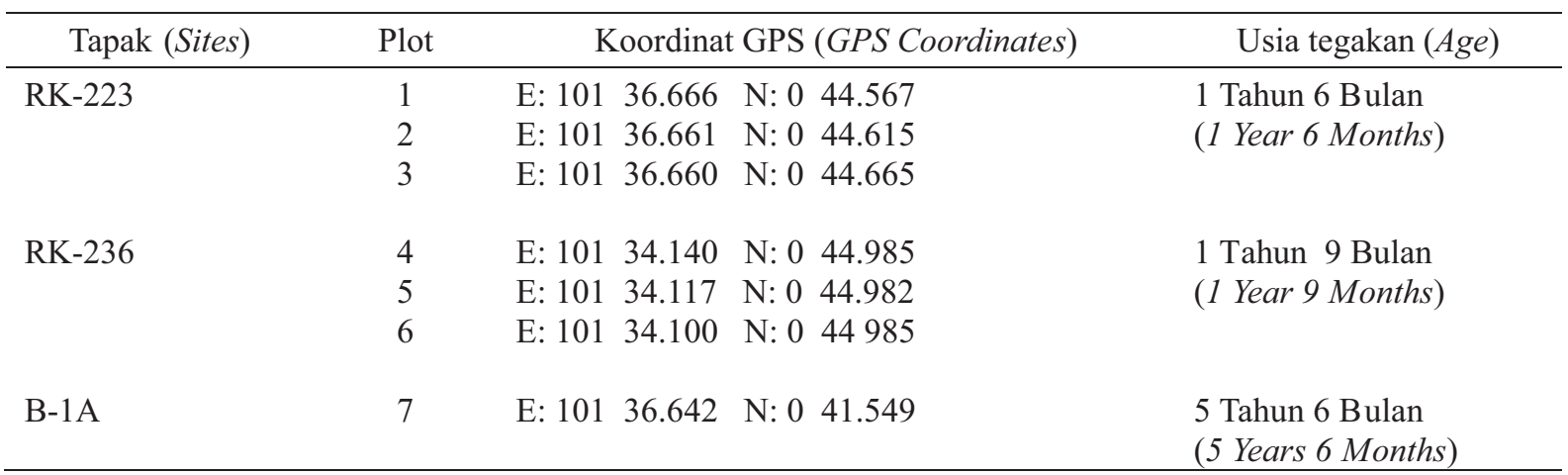


Tabel (Table) 2. Klasifikasi kondisi tajuk E. pellita (E. pellita crown condition classes)

\begin{tabular}{|c|c|}
\hline Kelas (Class) & Deskripsi (Description) \\
\hline 0 Mati (Dead) & $\begin{array}{l}\text { Pohon mati, tidak ada tajuk atau bahkan sudah tumbang (Tree recently dead, crown } \\
\text { dead or fallen tree) }\end{array}$ \\
\hline $\begin{array}{l}1 \text { Sangat stress } \\
\text { (Severely } \\
\text { stressed) }\end{array}$ & $\begin{array}{l}\text { Pohon tampak kerdil dibandingkan tegakan disekitarnya, tajuk tidak rapat dan } \\
\text { didominasi oleh dedaunan yang menguning, pada beberapa bagian dahan pohon terdapat } \\
\text { pucuk-pucuk muda (Tree height mostly suppressed, sparse crown dominated by } \\
\text { yellowing foliage, some epicormic growth present) }\end{array}$ \\
\hline 2 Stres (Stressed) & $\begin{array}{l}\text { Pohon cenderung lebih pendek dibandingkan tegakan di sekitarnya dengan tajuk yang } \\
\text { jarang, bisa ditumbuhi trubusan, berbunga dan/atau berbuah meskipun usia tanaman } \\
\text { masih muda, sebagai bentuk respons terhadap stres (Tree height partially suppressed } \\
\text { with sparse crown, epicormic shoots, flowers and/or fruit may be observed in response } \\
\text { to stress) }\end{array}$ \\
\hline $\begin{array}{l}3 \text { Agak stress } \\
\text { (Lightly } \\
\text { stressed) }\end{array}$ & $\begin{array}{l}\text { Pohon dengan tinggi rata-rata, memiliki tajuk yang agak rapat dengan daun-daun muda } \\
\text { dibagian luar tajuk (Sub dominant or co-dominant tree with moderate crown density and } \\
\text { some yellow green foliage) }\end{array}$ \\
\hline 4 Sehat (Healthy) & $\begin{array}{l}\text { Pohon dengan tinggi rata-rata dan memiliki tajuk yang rapat (Sub dominant or co- } \\
\text { dominant tree with a dense crown) }\end{array}$ \\
\hline $\begin{array}{l}5 \text { Sangat sehat } \\
\text { (Perfectly } \\
\text { healthy) }\end{array}$ & $\begin{array}{l}\text { Biasanya pohon tampak lebih tinggi dibandingkan tegakan disekitarnya, memiliki tajuk } \\
\text { yang rapat (Dominant tree with very dense crown and green foliage) }\end{array}$ \\
\hline
\end{tabular}
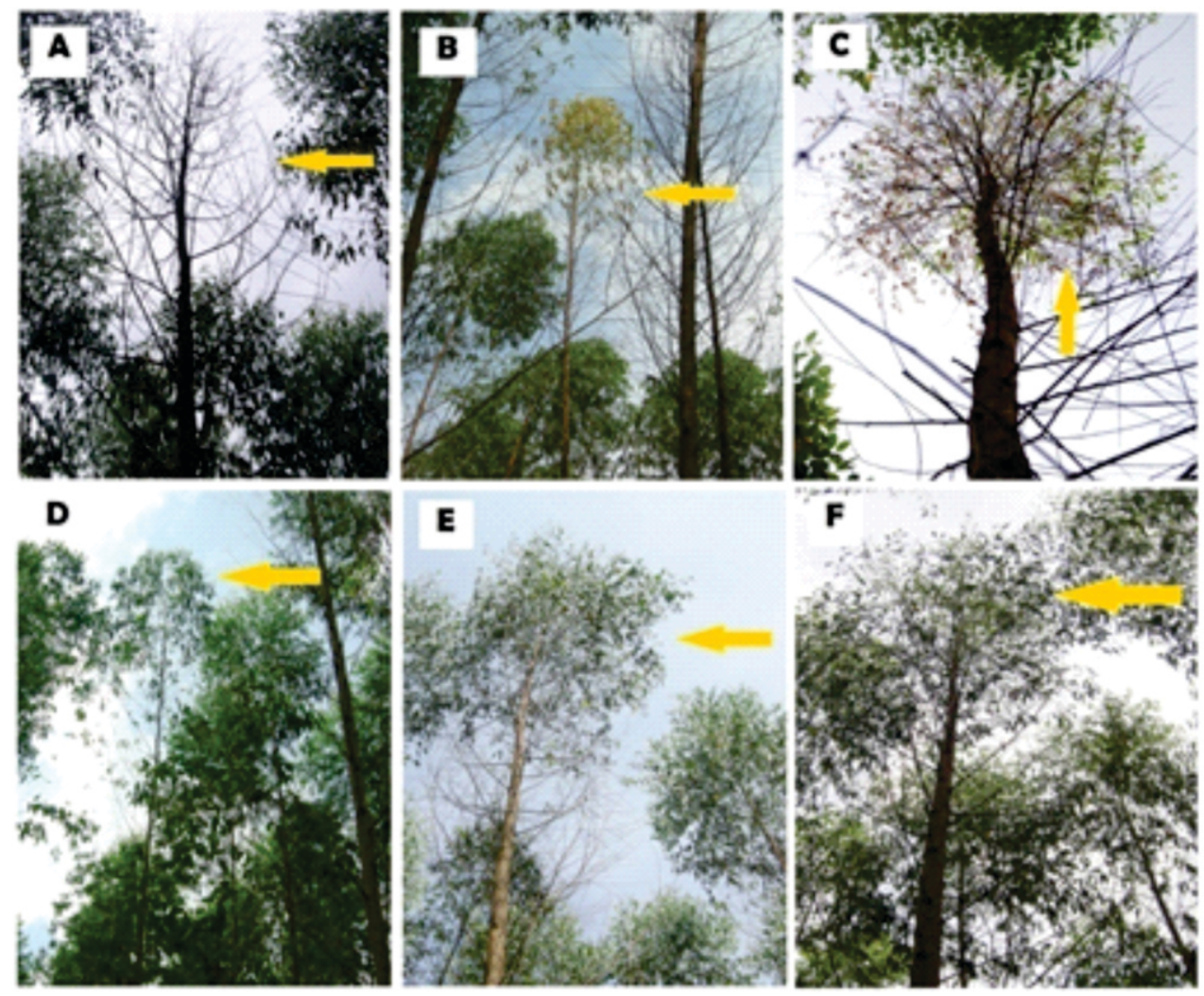

Gambar (Figure) 1. Foto rujukan untuk penentuan kelas kondisi tajuk E. pellita. (A) tajuk kelas 0, (B) tajuk kelas 1, (C) tajuk kelas 2, (D) tajuk kelas 3, (E) tajuk kelas 4, (F) tajuk kelas 5. (Reference pictures for the assessment of E. pellita crown conditions. (A) the crown was classified as 0 , (B) the crown was classified as 1, (C) the crown was classified as 2, (D) the crown was classified as 3, (E) the crown was classified as 4,(F) the crown was classified as 5) 
sentase infeksi ini ditentukan dari proporsi jumlah akar lateral yang terinfeksi terhadap jumlah total akar lateral, dikalikan $100 \%$. Infeksi akar ditentukan dari tanda (signs) hadirnya jamur penyebab busuk akar, yang dapat berupa adanya tubuh buah jamur patogen (Ganoderma sp. dan atau Phellinus sp.), miselia, rizomorf, pseudosclerotia dan lain-lain. Data persentase infeksi akar ini menjadi dasar untuk menentukan keberadaan (incidence) dan tingkat keparahan (severity) penyakit busuk akar yang menyerang $E$. pellita baik sebagai individu pohon maupun populasi tegakan.

Untuk menentukan incidence penyakit busuk akar, data infeksi akar dikelompokkan ke dalam 2 kategori, yaitu: (1) $0 \%$ (sehat) dan (2)>0\% (terinfeksi). Untuk menentukan tingkat keparahannya, data infeksi akar dikelompokkan ke dalam 4 kelas sebagai berikut: (1) terinfeksi seluruhnya (100\% akar terinfeksi); (2) terinfeksi banyak ( $\geq$ $50 \%$ akar terinfeksi); (3) terinfeksi sedikit (< $50 \%$ akar terinfeksi) dan (4) sehat (tidak ada akar yang terinfeksi). Interval kelas infeksi akar untuk menentukan tingkat severity ini berdasarkan struktur sebaran dan frekuensi data hasil pengamatan di lapangan dan kaitannya dengan kriteria incidence. Dalam studi untuk mendeskripsikan penyakit tanaman, incidence dan severity merupakan parameter yang selalu berkaitan.

\section{Aplikasi Metode Pengamatan Kondisi Tajuk dalam Mendeteksi Penyakit Busuk Akar}

Untuk mengetahui potensi aplikasi metode assessment kondisi tajuk dalam mendeteksi penyakit busuk akar (baik incidence maupun severity) dilakukan analisis statistik yang menghubungkan data pengamatan tajuk (terdiri atas variable: dominansi tajuk, tinggi pohon, diameter setinggi dada (DBH), kerapatan tajuk, rasio tajuk hidup, persentase daun muda, daun yang berwarna kuning kehijauan dan kuning dengan data pengamatan perakaran.

\section{E. Analisis Statistik}

Beberapa metode analisis statistik yang terdapat dalam program XLStat $2016^{\circledR}$ digunakan dalam studi ini. Repeatability dan reproducibility metode ini ditentukan dengan metoda oneway ANOVA pada tingkat kepercayaan $\alpha=0,05$; Reliability ditentukan berdasarkan discriminant analysis yang diterapkan pada dataset hasil penilaian pada survey I, II dan III. Kelas kondisi tajuk ditetapkan sebagai dependent variable; tujuh kuantitatif explanatory variable (tinggi pohon, DBH, kerapatan tajuk, rasio tajuk hidup, persentase daun muda, persentase daun berwarna kuning dan kuning kehijauan dan dominansi pohon sebagai kualitatif explanatory variable). Pengaruh relatif setiap variable dalam penentuan klasifikasi kondisi tajuk dilihat dari koefisien kanonikal standard fungsi diskriminan $(\beta)$. Semakin besar nilai $\beta$ semakin besar kontribusi variabel tersebut dalam membedakan kelas-kelas tersebut (Poulsen \& French, 2009).

\section{HASIL DAN PEMBAHASAN}

\section{A. Metode Pengamatan Kondisi Tajuk}

\section{Repeatability dan reproducibility}

Repeatability ditentukan dengan membandingkan data pengamatan di pagi hari dan sore hari untuk setiap asesor. Pada Tabel 3 dapat dilihat bahwa baik asesor 1 maupun asesor 2 tidak memiliki perbedaan nilai yang signifikan pada setiap indikator yang diamati. Asesor 3 menunjukkan variasi atau ketidakkonsistenan dalam menilai kelas kondisi tajuk dan persentase daun berwarna kuning (Tabel 3).

Reproducibility ditentukan dengan membandingkan data antar asesor pada waktu pengamatan yang sama. Data pada Tabel 3 menunjukkan bahwa asesor 3 cenderung memberikan nilai yang lebih tinggi untuk kelas kondisi tajuk dan nilai yang lebih rendah untuk persentase daun muda dan daun yang berwarna kuning. Namun variasi data pada asesor 3 (yang merupakan asesor yang relatif kurang berpengalaman) masih dalam kisaran yang dapat diterima untuk sebuah visual assessment (Horton et al., 2011). Hal ini dapat dikatakan bahwa metode ini repeatable dan reproducible meskipun diaplikasikan oleh asesor yang hanya memperoleh pelatihan dan pengarahan singkat di lapangan.

\section{Reliability}

Reliability ditentukan dengan membandingkan nilai $\beta$ setiap indikator dari survey I, II dan III (Tabel 4). Indikator dengan nilai $\beta$ tertinggi merupakan variabel yang paling mempengaruhi asesor dalam menentukan sehat tidaknya pohon yang diamati. Tim asesor pada survey I dan II memiliki kecenderungan yang sama, yaitu menggunakan indikator kerapatan tajuk sebagai penentu status kesehatan suatu pohon $(\beta=0,706$ pada survey I dan $\beta=0,903$ pada survey II) dan kerdilnya pohon (dominansi tajuk: suppressed) 
Tabel (Table) 3. Mean ( \pm SE) dari indikator tajuk yang diestimasi secara visual pada pagi dan sore hari oleh 3 asesor yang berbeda. (Means ( \pm SE) of the visual estimation for three different assessors in the morning and afternoon)

\begin{tabular}{|c|c|c|c|c|c|c|}
\hline \multirow[b]{2}{*}{$\begin{array}{c}\text { Penilai } \\
\text { (Assessors) }\end{array}$} & \multirow[b]{2}{*}{$\begin{array}{l}\text { Waktu } \\
\text { (Time) }\end{array}$} & \multicolumn{5}{|c|}{ Indikator tajuk (Crown indicators) } \\
\hline & & $\begin{array}{l}\text { Kelas kondisi } \\
\text { tajuk (Crown } \\
\text { condition } \\
\text { class) }\end{array}$ & $\begin{array}{c}\text { \% Kerapatan } \\
\text { tajuk (\% Crown } \\
\text { density) }\end{array}$ & $\begin{array}{l}\text { \% Daun muda } \\
\text { (\% New } \\
\text { foliage) }\end{array}$ & $\begin{array}{l}\text { \% Daun kuning } \\
\text { kehijauan } \\
(\% \text { Yellow green } \\
\text { foliage })\end{array}$ & $\begin{array}{l}\text { \% Daun kuning } \\
\text { (\% Yellow } \\
\text { foliage) }\end{array}$ \\
\hline \multirow[b]{2}{*}{1} & $\begin{array}{l}\text { Pagi } \\
\text { (AM) }\end{array}$ & $3,8 \pm 0,14^{\mathrm{c}}$ & $71,9 \pm 2,08^{a}$ & $21,3 \pm 2,02 a b$ & $15,6 \pm 2,58^{a}$ & $11,3 \pm 1,25^{\mathrm{a}}$ \\
\hline & $\begin{array}{l}\text { Sore } \\
(\mathrm{PM})\end{array}$ & $3,7 \pm 0,14^{c}$ & $71,3 \pm 2,56^{\mathrm{a}}$ & $21,3 \pm 2,21 a b$ & $15,6 \pm 2,73^{a}$ & $11,9 \pm 1,64^{\mathrm{a}}$ \\
\hline \multirow[t]{2}{*}{2} & $\begin{array}{l}\text { Pagi } \\
\text { (AM) }\end{array}$ & $3,9 \pm 0,10 b c$ & $70,6 \pm 2,32 \mathrm{a}$ & $20,6 \pm 2,13 \mathrm{ab}$ & $15,6 \pm 2,03$ a & $11,9 \pm 1,01^{\mathrm{a}}$ \\
\hline & $\begin{array}{l}\text { Sore } \\
(\mathrm{PM})\end{array}$ & $4,0 \pm 0,11 \mathrm{bc}$ & $70,0 \pm 2,42 \mathrm{a}$ & $23,8 \pm 2,21^{\mathrm{a}}$ & $13,8 \pm 2,21^{a}$ & $10,6 \pm 0,63^{a}$ \\
\hline \multirow[t]{2}{*}{3} & $\begin{array}{l}\text { Pagi } \\
\text { (AM) }\end{array}$ & $4,2 \pm 0,08^{b}$ & $71,3 \pm 2,39$ a & $17,5 \pm 1,44^{b}$ & $15,0 \pm 2,24^{\mathrm{a}}$ & $6,9 \pm 1,50 \mathrm{~b}$ \\
\hline & $\begin{array}{l}\text { Sore } \\
\text { (PM) }\end{array}$ & $4,9 \pm 0,09^{\mathrm{a}}$ & $7, .9 \pm 3,19^{a}$ & $16,9 \pm 1,51^{b}$ & $19,4 \pm 2,95 \mathrm{a}^{\mathrm{a}}$ & $1,3 \pm 1,25^{c}$ \\
\hline
\end{tabular}

Keterangan(Remaks): Angka yang diikuti oleh huruf yang berbeda pada kolom yang sama adalah berbeda secara signifikan pada $\alpha=0,05$ berdasarkan ANOVA yang digunakan pada setiap indikator secara terpisah (The values followed with different letters within the same column are significantly different at significance level $\alpha=0.05$, as determined by ANOVAfor each indicator separately)

sebagai indikator yang paling mudah ditangkap secara visual untuk menggolongkan pohon tersebut sebagai tanaman yang tidak sehat. Hal ini ditandai dengan nilai $\beta$ yang negatif (Tabel 4 ). Namun pada survey III, preferensi ini berubah. Kerapatan tajuk tidak lagi dijadikan indikator utama dalam klasifikasi kondisi tajuk. Tim asesor pada survey III cenderung menggunakan tinggi pohon dan rasio tajuk hidup sebagai indikator tajuk yang menentukan pengelompokan kondisi kesehatan tegakan E. pellita pada plot-plot yang diamati. Tim asesor yang melakukan survey III tampaknya memiliki interpretasi yang berbeda terhadap deskripsi yang tercantum dalam Tabel 2.

Perbedaan koefisien kanonikal standar (standardised canonical coefficient) ini disebabkan ketiga survey ini dilakukan oleh tim yang berbeda-beda dan memiliki level pengalaman yang berbeda pula dalam hal pengamatan tajuk tanaman. Survey I dikerjakan oleh tim yang dipimpin oleh asesor yang telah memiliki pengalaman dalam hal pengamatan tajuk. Survey II dikerjakan oleh tim yang sudah mendapatkan pelatihan dari tim survey I. Namun karena kendala teknis, tim survey II ini tidak dapat mengerjakan survey yang ketiga, sehingga survey III dikerjakan oleh tim baru yang mendapatkan penjelasan dan pelatihan yang kurang optimal.
Klasifikasi kondisi tajuk (Tabel 2) secara eksplisit menyebutkan kerapatan tajuk dan dominansi pohon sebagai faktor yang harus diperhitungkan saat menentukan kelas kondisi tajuk dari suatu pohon yang sedang diamati. Berdasarkan data pada Tabel 4, tim asesor yang melakukan survey I dan II tampaknya memiliki pemahaman yang sama mengenai deskripsi kondisi tajuk dalam metode penilaian tajuk ini. Hasil analisis statatistik menunjukkan bahwa akurasi dataset survey I sebesar $73 \%$ dan survey II sebesar $61 \%$. Adapun tim asesor yang melakukan survey III tampak memiliki kesulitan untuk memahami dan mengaplikasikan deskripsi pada Tabel 2 tersebut, sehingga penilaian kondisi tajuk lebih dipengaruhi oleh tinggi pohon dan rasio tajuk hidup.

Kerapatan tajuk, merupakan parameter yang telah umum digunakan untuk menunjukkan kondisi kesehatan pohon (Schomaker et al., 2007). Tajuk yang rapat merupakan indikasi tanaman yang sehat, sebaliknya tajuk yang jarang berasosiasi dengan kondisi tanaman yang sedang mengalami stres (Morin et al., 2015). Namun demikian, suatu tanaman tidak secara langsung dianggap sehat hanya karena memiliki tajuk yang rapat (Morin et al., 2015). Studi dan observasi yang lebih komprehensif diperlukan untuk me- 
Tabel (Table) 4. Nilai koefisien fungsi canonical discriminant terstandar $(\beta)$ indikator tajuk dari dataset 3 kali survey (The standardised canonical discriminant coefficient ( $\beta$ ) of crown indicators for the three survey)

\begin{tabular}{lccc}
\hline \multicolumn{1}{c}{$\begin{array}{c}\text { Indikator pada tajuk } \\
\text { (Crown indicators) }\end{array}$} & \multicolumn{3}{c}{ Koefisien kanonikal standard ( $\beta$ ) } \\
& Standardised canonical coefficient) \\
\cline { 2 - 4 } & Survey I & Survey II & Survey III \\
\hline Dominansi tajuk (Crown dominance): & $-0,185$ & 0,104 & 0,191 \\
Dominant & 0,000 & 0,000 & 0,000 \\
Sub (Co-dominat) & $-0,634^{*}$ & $-0,502^{*}$ & $-0,095$ \\
Suppressed & $-0,168$ & 0,031 & $0,777^{*}$ \\
Tinggi pohon (Tree height) & 0,130 & 0,269 & 0,060 \\
Diameter setinggi dada (Diameter at breast height) & $0,706^{*}$ & $0,903^{*}$ & 0,393 \\
Kerapatan tajuk (Crown density) & 0,260 & $-0,042$ & $0,501^{*}$ \\
Rasio tajuk hidup (Live crown ratio) & 0,194 & $-0,088$ & $-0,001$ \\
Persentase daun muda (Percentage of new foliage) & $-0,082$ & $-0,163$ & 0,020 \\
Persentase daun kuning kehijauan (Percentage of yellow & & & \\
green foliage) & 0,176 & 0,315 & 0,175 \\
Persentase daun kuning (Percentage of yellow foliage) & & & \\
\hline
\end{tabular}

Keterangan (Remaks): Nilai $\beta$ yang diberi tanda bintang merupakan indikator yang paling berpengaruh terhadap pengelompokan kondisi tajuk (The asteric $\beta$ values having the most influence on the discriminant function)

nentukan status kesehatan tanaman. Pengukuran parameter yang diestimasi secara visual, tingkat keahlian dan pengalaman asesor ternyata mempengaruhi tingkat akurasi data yang diperoleh (Horton et al., 2011). Studi ini pun memperkuat hal tersebut. Hal ini menunjukkan bahwa untuk mendapatkan data yang reliable (akurat) diperlukan pemahaman yang benar dan seragam terhadap metode assessment yang digunakan. Oleh karena itu, para asesor perlu memperoleh pelatihan yang memadai.

\section{B. Kondisi Tajuk sebagai Indikasi Penyakit Busuk Akar}

Upaya untuk menguji potensi kondisi tajuk sebagai indikator penyakit busuk akar, penelitian ini telah menghubungkan data kondisi tajuk dengan kondisi perakaran E. pellita. Data kondisi tajuk yang digunakan adalah data yang dihasilkan dari penilaian oleh pengamat I pada survey I, yang menunjukkan nilai paling konsisten dan reliable berdasarkan uji repeatability dan realiability.

Berdasarkan korelasi Spearman, kondisi tajuk berkorelasi secara signifikan $(\alpha=0,05 ; \mathrm{p}<$ $0,0001)$ dengan infeksi penyakit busuk akar. Hal ini menunjukkan bahwa pada level plot, dimana kondisi keseluruhan plot (termasuk pohon yang sudah mati) dimasukkan dalam analisis, dampak serangan penyakit busuk akar tersebut mempengaruhi secara signifikan kesan yang tampak pada tajuk di plot tersebut. Namun, saat analisis hanya diberlakukan pada data dari pohon yang hidup saja (tanpa memasukkan skor nol), koefisien korelasi Spearman menunjukkan nilai yang tidak signifikan (Tabel 5). Hal ini menunjukkan bahwa kondisi tajuk E. pellita tidak secara signifikan mengindikasikan penyakit busuk akar yang diduga telah menyerang pohon-pohon yang masih hidup tersebut.

Untuk menghitung probabilitas kondisi tajuk sebagai indikator penyakit busuk akar digunakan discriminant analysis, yang menunjukkan bahwa akurasi kondisi tajuk sebagai indikator penyakit busuk akar (root rot incidence) adalah 61,4\% sedangkan sebagai indikator tingkat keparahan (severity) adalah 41,6\% (Tabel 6 dan Tabel 7). Nilai prediksi ini masih sekitar nilai sebuah dugaan acak (50:50). Oleh karena itu, dapat dikatakan bahwa penyakit busuk akar masih sulit dideteksi apabila hanya mengandalkan gejalagejala yang tampak pada tajuk.

Infeksi penyakit busuk akar memang sering kali tidak terdeteksi dari gejala yang tampak pada tajuk. Penyakit busuk akar pada fase awal sampai intermediate sulit terdeteksi dan baru akan mempengaruhi kondisi tajuk setelah akar terinfeksi parah (Farid et al., 2006). Sebagai contoh, Francis et al. (2014) yang memonitor penyebaran penyakit busuk akar pada $A$. mangium pada kurun waktu 2007-2009 di beberapa lokasi di Riau, Sumatera Selatan dan Kalimantan Timur, melaporkan bahwa $97 \%$ pohon yang positif terinfeksi G. philippii (patogen busuk akar) ber- 
Tabel(Table) 5. Koefisien korelasi Spearman (S) dari indikator tajuk dengan kelas keparahan infeksi penyakit busuk akar (Spearman's correlation (S) of the crown indicators and root rot severity classes)

\begin{tabular}{|c|c|c|c|c|}
\hline \multirow{3}{*}{ Indikator (Indicators) } & \multicolumn{4}{|c|}{$\begin{array}{l}\text { Kelas keparahan penyakit busuk akar } \\
\text { (Root rot severity classes) }\end{array}$} \\
\hline & \multicolumn{2}{|c|}{$\begin{array}{l}\text { Pohon mati dihitung } \\
\text { (Dead tree included) }\end{array}$} & \multicolumn{2}{|c|}{$\begin{array}{l}\text { Pohon mati tidak dihitung } \\
\text { (Dead tree excluded })\end{array}$} \\
\hline & $\mathrm{S}$ & $\mathrm{p}$-value & $\mathrm{S}$ & $\mathrm{p}$-value \\
\hline Dominansi tajuk (Crown dominance) & 0,711 & $<0,0001$ & 0,120 & 0,086 \\
\hline Tinggi pohon (Tree height) & 0,650 & $<0,0001$ & 0,012 & 0,864 \\
\hline DBH (Diameter at breast height) & 0,656 & $<0,0001$ & 0,020 & 0,775 \\
\hline Kerapatan tajuk (Crown density) & 0,683 & $<0,0001$ & 0,102 & 0,143 \\
\hline Rasio tajuk hidup (Live crown ratio) & 0,675 & $<0,0001$ & 0,069 & 0.322 \\
\hline $\begin{array}{l}\text { Persentase daun muda (Percentage of new } \\
\text { foliage) }\end{array}$ & 0,661 & $<0,0001$ & $-0,016$ & 0,814 \\
\hline $\begin{array}{l}\text { Persentase daun kuning kehijauan } \\
\text { (Percentage of yellow green foliage) }\end{array}$ & 0,652 & $<0,0001$ & $-0,051$ & 0,468 \\
\hline $\begin{array}{l}\text { Persentase daun kuning (Percentage of yellow } \\
\text { foliage) }\end{array}$ & 0,488 & $<0,0001$ & 0,057 & 0,416 \\
\hline
\end{tabular}

Tabel (Table) 6. Akurasi indikator tajuk sebagai penduga keberadaan penyakit busuk akar (Acuration of crown indicators to indicate rootrot incidence)

\begin{tabular}{ccccc}
\hline \multicolumn{2}{c}{$\begin{array}{c}\text { Observasi actual } \\
\text { (Actual observation) }\end{array}$} & $\begin{array}{c}\text { Prediksi pengelompokan } \\
\text { (Predicted group memberships) }\end{array}$ & $\begin{array}{c}\text { \% Kesesuaian } \\
\text { \% Correct })\end{array}$ \\
\cline { 1 - 3 } Kelompok (Groups) & $\begin{array}{c}\text { Jumlah pohon } \\
\text { (Number of trees) }\end{array}$ & $\begin{array}{c}\text { Terinfeksi } \\
\text { (Infected) }\end{array}$ & Sehat (Healthy) & \\
\hline Terinfeksi (Infected) & 48 & 30 & 18 & 62,5 \\
Sehat (Healthy) & 159 & 62 & 97 & 61,0 \\
Total & 207 & & & 61,4 \\
\hline
\end{tabular}

Tabel(Table) 7. Akurasi indikator tajuk sebagai penduga tingkat keparahan penyakit busuk akar (Accuration of crown indicators to indicate root rot severity)

\begin{tabular}{|c|c|c|c|c|c|c|}
\hline \multicolumn{2}{|c|}{$\begin{array}{l}\text { Observasi actual } \\
\text { (Actual observation) }\end{array}$} & \multicolumn{4}{|c|}{$\begin{array}{c}\text { Prediksi pengelompokan } \\
\text { (Predicted group memberships) }\end{array}$} & \multirow{2}{*}{$\begin{array}{c}\% \\
\text { Kesesuaian } \\
(\% \text { Correct })\end{array}$} \\
\hline Kelompok (Groups) & $\begin{array}{l}\text { Jumlah } \\
\text { pohon } \\
\text { (Number } \\
\text { of trees) }\end{array}$ & $\begin{array}{l}\text { Sehat } \\
\text { (Healthy) }\end{array}$ & $\begin{array}{c}\text { Terinfeksi } \\
\text { sedikit } \\
\text { (Partly } \\
\text { infected) }\end{array}$ & $\begin{array}{c}\text { Terinfeksi } \\
\text { banyak } \\
\text { (Highly } \\
\text { infected) }\end{array}$ & $\begin{array}{c}\text { Terinfeksi } \\
\text { seluruhnya } \\
\text { (Totally } \\
\text { infected) }\end{array}$ & \\
\hline Sehat (Healthy) & 159 & 58 & 16 & 44 & 41 & 36,5 \\
\hline $\begin{array}{l}\text { Terinfeksi sedikit (Partly } \\
\text { infected) }\end{array}$ & 24 & 7 & 11 & 1 & 5 & 45,8 \\
\hline $\begin{array}{l}\text { Terinfeksi banyak } \\
\text { (Highly infected) }\end{array}$ & 12 & 0 & 2 & 9 & 1 & 75,0 \\
\hline $\begin{array}{l}\text { Terinfeksi seluruh } \\
\text { (Totally infected) }\end{array}$ & 12 & 2 & 2 & 0 & 8 & 66,7 \\
\hline Total & 207 & & & & & 41,6 \\
\hline
\end{tabular}


dasarkan pengamatan perakaran, masih menunjukkan kondisi tajuk yang sehat, hanya 3\% saja yang menunjukkan kondisi tajuk yang menguning. Penyakit busuk pangkal batang (basal stem rot) pada tegakan kelapa sawit, gejala pada tajuk umumnya dapat diamati setelah separuh $( \pm 50 \%)$ sistem perakarannya mati karena serangan patogen G. boninense (Mohammed et al., 2014). Karena inilah, penyakit busuk akar seringkali disebut sebagai sudden death disease.

Sampai saat ini upaya untuk mengembangkan metode deteksi dini untuk penyakit busuk akar pada individual pohon, masih merupakan tantangan yang besar. Namun, untuk skala plot atau kompartemen metode prediksi serangan penyakit busuk akar masih memungkinkan untuk dikembangkan, agar kerugian jangka panjang yang lebih besar dapat dikurangi. Penyebaran busuk akar umumnya melalui kontak akar yang terinfeksi dengan akar yang masih sehat (Eyles, et al., 2008; Irianto et al., 2006; Lockman et al., 2016). Oleh karena itu, pohon yang tumbuh di dekat pohon yang terinfeksi berpotensi untuk terinfeksi juga. Semakin banyak jumlah pohon terinfeksi di sekeliling pohon yang masih tampak sehat, maka semakin besar peluang pohon yang sehat tersebut untuk terinfeksi juga (Francis et al., 2014). Perlu dilakukan studi lebih lanjut untuk menguji apakah parameter ini dapat menjadi indikator komplementer untuk indikator-indikator tajuk dalam memprediksi penyakit busuk akar.

Fungi penyebab penyakit busuk akar, seperti : $G$. boninense yang menyerang perkebunan kelapa sawit; G. philippii yang menyerang HTI akasia dan ekaliptus; Phellinus noxius yang menyerang jati (Tectona grandis), sentang (Azadirachta exelsa) dan A. mangium; Rigidoporus microporus syn $R$. lignosus yang menyerang perkebunan karet (Hevea brasiliensis) (Agustini et al., 2014; Bivi et al., 2010; Farid et al., 2009; Francis et al., 2014; Irianto et al., 2006; Oghenekaro et al., 2014; Rees et al., 2009) pada dasarnya merupakan komponen normal pada ekosistem hutan alam. Pada ekosistem alami, interaksi fungi-fungi tersebut dengan tanaman inang berpengaruh terhadap siklus nutrisi, komposisi dan struktur hutan supaya tetap dalam keseimbangan dinamis (dynamic equilibrium) (Loo, 2009; Pautasso et al., 2012). Dibukanya perkebunan dan HTI yang umumnya menanam tanaman eksotik dalam skala yang sangat luas secara monokultur, keseimbangan dinamis ini menjadi terganggu. Fungi, yang pada ekosistem alaminya cenderung berperan sebagai saprofit, dapat berubah menjadi agen biotik yang bersifat parasit bagi komoditas tanaman perkebunan dan HTI (Lutz \& Halpern, 2006) dan dapat mengakibatkan kerugian ekonomi yang tidak sedikit. Hal tersebut menjadi resiko yang harus ditanggung dari upaya pemenuhan kebutuhan manusia terhadap komoditas-komoditas HTI dan perkebunan tersebut.

Untuk mengurangi potensi kerugian ekonomi dalam pengelolaan HTI dan mengingat belum adanya teknik pengendalian penyakit busuk akar yang efektif dan dapat diaplikasikan dalam skala luas, maka menghindari penanaman komoditas HTI dan perkebunan di areal yang beresiko tinggi terserang patogen busuk akar merupakan salah satu upaya pencegahan terjadinya outbreak penyakit ini. Oleh karena itu, site risk assessment terkait penyakit busuk akar perlu dilakukan sebelum membuka suatu lahan/kawasan untuk HTI atau perkebunan, agar potensi kerugian ekonomis dan ekologis akibat pembukaan HTI dan/atau perkebunan tersebut dapat dicegah atau dikurangi.

\section{KESIMPULAN DAN SARAN}

Metode pengamatan kondisi tajuk yang dikembangkan dalam studi ini dapat digunakan untuk memonitor perubahan-perubahan yang tampak pada tajuk, dengan catatan proses pengamatannya dilakukan oleh tenaga-tenaga yang berpengalaman/terlatih. Pada level plot, kondisi tajuk E. pellita secara signifikan berkorelasi dengan serangan penyakit busuk akar. Namun, penyakit busuk akar pada level individu pohon masih sulit dideteksi apabila hanya mengandalkan gejala-gejala yang tampak pada tajuk. Probabilitas kondisi tajuk E. pellita sebagai penduga penyakit busuk akar sebesar $61,4 \%$ sedangkan sebagai indikator tingkat keparahannya adalah 41,6\%. Metode deteksi dini penyakit busuk akar masih perlu dikaji dari berbagai aspek, baik tanaman inang, patogen, faktor-faktor lingkungan serta dinamika ekosistem yang berpengaruh terhadap outbreaks penyakit ini. Survey untuk menilai potensi suatu kawasan terhadap resiko terserang penyakit busuk akar (root rot site risk assessment) perlu dilakukan sebelum pembukaan HTI agar kerugian akibat penyakit busuk akar dapat dihindari. 


\section{UCAPAN TERIMA KASIH}

Penulis mengucapkan terima kasih kepada Assoc. Prof. Caroline Mohammed, Dr. Karen Barry, Dr. Anthony Francis dan Dr. Bryony Horton dari University of Tasmania, dan Dr. Chris Beadle dari CSIRO-Sustainable Ecosystem di Hobart, yang telah mengenalkan penulis pada bidang Forest Health Assessmenst dan Ir. Mardai Unen, Ir. Heru Indrayadi, Fadjar Sagitarianto, S.Hut., Bayo Alhusairi, M.Sc. yang telah memfasilitasi kelancaran studi ini.

\section{DAFTAR PUSTAKA}

Agustini, L., Glen, M., Indrayadi, H., Wahyuno, D., Sagitarianto, F., \& Alhusairi, B. (2013). Root rot in Eucalyptus pellita plantations and its possible biocontrol. In: S.S. Lee, A.F. Mas'ud, C.A. Siregar, Pratiwi, N. Mindawati, G. Pari, M. Turjaman, Krisdianto, H. Krisnawati, I.Z. Siregar, W. Laba, A. Mardiastuti, I. Wahyudi (editor). 'Proceedings of the $2^{\text {nd }}$ International Conference of Indonesia Forestry Researchers'. 27-28 August 2013. Jakarta.

Agustini, L., Francis, A., Glen, M., Indrayadi, H., \& Mohammed, C.L. (2014). Signs and identification of fungal root rot pathogen in tropical Eucalyptus pellita plantations. Forest Pathology. 44: 486-495.

Agustini, L., Beadle, C., Barry, K., \& Mohammed, C.L. (2015). Photosynthetic responses of Eucalyptus nitens at initial stages of root rot infection. Indonesian Journal of Forestry Research.2(1): 9-20.

Bakys, R., Vasiliauskas, A., Ihrmark, K., Stenlid, J., Menkis, A., \& Vasaitis, R. (2011). Root rot associated fungi and their impact on health condition of declining Fraxinus excelsior stands in Lithuania. Scandinavian Journal of Forest Research. 26: 128-135.

Bartlett, J.W. \& Frost, C. (2008). Reliability, repeatability and reproducibility: analysis of measurement errors in continous variables. Journal Ultrasound in Obstetrics \& Gynecology.31(4): 466-475.

Berger, S., Sinha, A.K. \& Roitsch, T. (2007). Plant physiology meets phytopathology: Plant Primary metabolism and plant-pathogen interactions. Journal of Experimental Botany. 58(15-16): 4019-4026.

Brazee, N.J. \& Wick, R.L. (2009). Armillaria species distribution on symptomatic hosts in northern hardwood and mixed oak forests in western Massachusetts. Forest Ecology and Management 258: 1605-1612.
Carnegie, A.J. (2007). Forest health condition in New South Wales, Australia, 1996-2005. II. Fungal damage recorded in eucalypt plantation during forest health surveys and their management. Australian Plant Pathology. 36: 225-239.

Carnicer, J., Coll, M., Ninyerola, M., Pons, X., Sanchez, G. \& Penuelas, J. (2011). Wide spread crown condition decline, food web discruption and amplified tree mortality with increased climate change type drought. PNAS. 108(4): 1474-1478.

Cunningham, S.C., Read, J., Baker, P.J., \& Nally, R.M. (2007). Quantitative assessment of stand condition and its relationship to physiological stress in stands of Eucalyptus camaldulensis (Myrtaceae). Australian Journal of Botany. 55: $1-8$

Eyles, A., Beadle, C., Barry, K., Francis, A., Glen, M. \& Mohammed, C. (2008). Management of fungal root rot pathogens in tropical Acacia mangium Willd. plantations. Forest Pathology. 38: $332-355$

Farid, A.M. \& Lee, S.S. (2006). Root rot in tree species other than Acacia. In: K. Potter, A. Rimbawanto and C. Beadle (eds.). 'Heart rot and root rot in tropical Acacia plantations'. ACIAR Proceedings No.124. Yogyakarta.

Farid, A.M., Lee, S.S., Maziah, Z., \& Patahayah, M. (2009). Pathogenecity of Rigidoporus microporus and Phellinus noxius against four major plantation tree species in peninsular Malaysia. Journal of Tropical Forest Science. 21(4): 289298.

Francis, A., Beadle, C., Puspitasari, D., Irianto, R., Agustini, L., Rimbawanto, A., Gafur, A., Hardiyanto, E., Junarto, Hidayati., N., Tjahjono, B., Mardai, U., Glen, M. \& Mohammed, C. (2014). Disease progression in plantations of Acacia mangium affected by red root rot (Ganoderma phillippii). Forest Pathology. $44: 447-459$.

Glen, M., Bougher, N.L., Francis, A.A., Nigg, S.Q., Lee, S.S., Irianto, R., Barry, K.M., Beadle, C.L., \& Mohammed, C.L. (2009). Ganoderma and Amauroderma species associated with root-rot disease of Acacia mangium Willd. plantation trees in Indonesia and Malaysia. Australian Plant Pathology. 38: 345-356.

Horton, B.M., Close, D.C., Wardlaw, T.J., \& Davidson, N.J. (2011). Crown condition assessment: An accurate, precise and efficient method with broad applicability to Eucalyptus. Austral Ecology. 36: 709-721.

Irianto, R.S.B., Barry, K., Hidayati, N., Ito, S., Fiani, A., Rimbawanto, A., \&Mohammed, C. (2006). Incidence and spatial analysis of root rot of 
Acacia mangium Willd. in Indonesia. Journal of Tropical Forest Science. 18: 157-165.

Lockman, I.B. \& Kearns, H.S.J. (2016). Forest root diseases across the United States. Gen. Tech. Rep. RMRS-GTR-342. Ogden, UT : USDA Forest Service, Rocky Mountain Research Station. 55p.

Loo, J.A. (2009). Ecological impacts of nonindigenous invasive fungi as forest pathogens. Biol. Invasions. 11: 81-96.

Lutz, J.A. \& Halpern, C.B. (2006). Tree mortality during early forest development: A long-term study of rates, causes and consequences. Ecological Monographs, 76(2): 257-275.

Mohammed, C.L., Rimbawanto, A., \& Page, D.E. (2014). Management of basidiomycete rootand stem-rot diseases in oil palm, rubber and tropical hardwood plantation crops. Forest Pathology. 44: 428-446.

Morin, R.S., Randolph, K.C., \& Steinman, J. (2015). Mortality rates associated with crown health for eastern forest tree species. Environmental Monitoring and Assessment, 187(87): 1-11.

Oghenekaro, A.O., Miettinen, O., Omorusi, V.I., Evueh, G.A., Farid, M.A., Gazis, R. \& Asiegbu, F.O. (2014). Molecular phylogeny of Rigidoporus microporus isolated associated with white rot diseases of rubber trees (Hevea brasiliensis). Fungal Biology. 118(5-6): 495506.

Pautasso, M., Doring, T.F., Garbelotto, M., Pellis, L., \& Jeger, M.J. (2012). Impact of climate change on plant diseases-opinions and trends. European Journal of Plant Pathology. 133: 295-313.

Pautasso, M., Schlegel, M., \& Holdenreider, O. (2015). Forest health in a changing world. Microbial Ecology. 69: 826-842.

Poulsen, J., \& French, A. (2009). Discriminant function analysis. http://userwww.sfsu.edu/ $\sim$ efc/classes/biol710/discrim/discrim. Diakses 18 Mei 2009.
Rees, R.W., Flood, J., Hasan, Y., Potter, U., \& Cooper, R.M. (2009). Basal stem tot of oil palm (Elaeis guineensis): mode of root infection and lower stem invasion by Ganoderma boninense. Plant Pathology. 58: 982-989.

Schomaker, M.E., Zarnoch, S.J., Benchtold, W.A., Latelle, D.J., Burkman, W.G. \& Cox, S.M. (2007). Crown condition classification: a guide to data collection and analysis. Asheville, N.C., Forest service-United State Departement of Agriculture.

Smith, R.R., Mc Crary, S., \& Callahan, R.N. (2007). Gauge repeatability and reproducibility studies and measurement system analysis: a multimethod exploration of the state of practice. Journal of Industrial Technology. 23: $1-12$.

Stone, C. \&Haywood, A. (2006). Assessing canopy health of native eucalypt forests. Ecological Management \& Restoration. 7(S1): S24-S30.

Sulichantini, E.D. (2016). Pertumbuhan tanaman Eucalyptus pellita F. Muell. di lapangan dengan menggunakan bibit hasil perbanyakan dengan metode kultur jaringan, stek pucuk dan biji.ZIRAA'AH. 41(2): 269-275.

Vollenweider, P., \& Gunthardt-Goerg, M.S. (2006). Erratum to "diagnosis of abiotic and biotic stress factors using the visible symptoms in foliage" [Environ. Pollut. 137 (2005) 455465]. Environmental Pollution. 140: 562-571.

Wang, Y., Solberg, S., Yu, P., Myking, T., Vogt, R.D., \& Du, S. (2007). Assessments of tree crown condition of two manson pine forests in the acid rain region in China. Forest Ecology and Management. 242: 530-540.

Wolken, J.M., Lieffers, V.J., Landhausser, S.M., \& Mulak, T. (2009). Spring frost and decay fungi are implicated in suppressing aspen re-growth following partial cleaning in juvenile stands. Annals of Forest Science. 66: 805. 



\title{
PEMILIHAN JENIS HIBRID ULAT SUTERA YANG OPTIMAL UNTUK DIKEMBANGKAN DI DATARAN TINGGI DAN/ATAU DATARAN RENDAH
}

\author{
Selection of Silk Worm Hybrids for Silk Worm Rearing in Highland \\ and/or Lowland \\ Lincah Andadari \\ Pusat Penelitian dan Pengembang Hutan \\ Kampus Badan Litbang dan Inovasi, Jl. Gunung Batu No. 5 Kotak Pos 165 Bogor 16118 \\ Jawa Barat, Indonesia \\ Tlp. (0251) 8633234; Fax. (0251) 8638111 \\ E-mail: a.lincah@yahoo.co.id \\ Tanggal diterima : 20 Mei 2016; Tanggal revisi : 16 Juni 2016; Tanggal disetujui : 6 Juni 2016
}

\begin{abstract}
One constraints in natural silk industryin Indonesia is slow production and poor quality of cocoon. This is due to the use of same type of worm for diverse locations. This study aimed to obtain best silkworm for highlands and/or lowlands rearing. Four silkwormhybrids from Forest $R \& D$ Centre and one commercial hybrid from Perhutani were tested The experimental design using a split plot design in a randomized block design. The main plot was location altitude (highland and lowland) and subplot was silkworm hybrids ( $\mathrm{P} 3 \mathrm{H}-1, \mathrm{P} 3 \mathrm{H}-2, \mathrm{P} 3 \mathrm{H} 3, \mathrm{P} 3 \mathrm{H}-4$, and C3O1). The results showed that the rate of hatching silkworms were not affected by the hybrids and altitudes with hatching percentages were above $96 \%$ Three hybrids namely $\mathrm{P} 3 \mathrm{H}-1, \mathrm{P} 3 \mathrm{H}-2$, and $\mathrm{P} 3 \mathrm{H}-4$ are suitable to be reared in lowlands. Two hybrids namely $\mathrm{P} 3 \mathrm{H}-2$ and $\mathrm{P} 3 \mathrm{H}-3$ are suitable for highlands. $\mathrm{Hybrids} \mathrm{P} 3 \mathrm{H}-2$ are potentially reared in lowland and highland.
\end{abstract}

Keywords: Hybrid, productivity, silkworm

\begin{abstract}
ABSTRAK
Salah satu kendala dalam usaha persuteraan alam di Indonesia adalah masih rendahnya produksi dan kualitas kokon. Hal ini akibat penggunaan jenis ulat yang sama untuk lokasi yang beragam. Penelitian ini bertujuan untuk mendapatkan bibit ulat sutera yang optimal untuk dikembangkan di dataran tinggi dan/atau dataran rendah. Ulat sutera yang diujikan yaitu 4 hibrid ulat sutera dari Pusat Penelitian dan Pengembangan Hutan dan 1 hibrid dari Perum Perhutani. Penelitian menggunakan Rancangan Split Plot dalam Rancangan Acak Kelompok. Petak utama berupa lokasi dataran rendah dan dataran tinggi dan anak petak terdiri atas 5 jenis ulat sutera ( $\mathrm{P} 3 \mathrm{H}-1, \mathrm{P} 3 \mathrm{H}-2, \mathrm{P} 3 \mathrm{H}-3, \mathrm{P} 3 \mathrm{H}-4$ dan C301). Hasil penelitian menunjukkan bahwa tingkat penetasan ulat sutera tidak dipengaruhi oleh jenis ulat sutera maupun ketinggian lokasi pemeliharaan, dengan persentase penetasan di atas $96 \%$. Ulat sutera yang cocok dikembangkan di dataran rendah adalah hibrid P3H-1, P3H-2 dan P3H-4. Jenis hibrid yang sesuai untuk dibudidayakan di dataran tinggi yaitu $\mathrm{P} 3 \mathrm{H}-2$ dan $\mathrm{P} 3 \mathrm{H}-3$. Hibrid $\mathrm{P} 3 \mathrm{H}-2$ potensial untuk dikembangkan dataran rendah dan di dataran tinggi.
\end{abstract}

Kata kunci: Hybrid, produktivitas, ulat sutera

\section{PENDAhUluAN}

Indonesia mempunyai potensi untuk mengembangkan persuteraan alam, karena kondisi alamnya yang cocok untuk pertumbuhan ulat sutera maupun tanaman murbei sebagai pakannya. Kegiatan persuteraan alam bersifat padat karya mulai kegiatan budidaya, produksi dan industri. Hal ini, sangat mendukung program pemerintah dalam peningkatan lapangan kerja dan sekaligus meningkatkan pendapatan masyarakat pedesaan.

Usaha budidaya sutera alam membutuhkan ketekunan, hati-hati dan kesabaran terutama pada tahap pemeliharaan ulat sutera. Keberhasilan budidaya ulat sutera tergantung faktor pakan, bibit ulat, kondisi tempat pemeliharaan dan sistem pemeliharaan. Kualitas bibit menjadi salah satu faktor yang penting untuk diperhatikan. Rendahnya kualitas bibit dapat menurunkan 
kuantitas dan kualitas produksi kokon. Saat ini, persuteraan alam masih terkendala yaitu masih rendahnya produksi per satuan luas (Santoso, 2012). Penggunaan jenis ulat yang sama untuk pemeliharaan pada kondisi tempat yang beragam telah menimbulkan produksi kokon yang bervariasi (Andadari \& Kuntadi, 2014). Selama ini bibit ulat sutera komersil yang digunakan untuk berbagai kondisi lingkungan menggunakan hibrid C301. Sejak tahun 1928 semua bibit komersil ulat sutera merupakan hasil persilangan antara ras Jepang dengan ras Cina. Pada umumnya, ras Jepang mempunyai kualitas filamen sutera yang baik sementara ras Cina lebih kuat, kandungan suteranya tinggi dan umurnya lebih pendek (Kaomini \& Andadari, 2009). Padahal hibrid C301 mempunyai daya tahan yang rendah terhadap perubahan kondisi lingkungan (Kaomini \& Andadari, 2009).

Untuk meningkatkan produksi dan kualitas kokon, maka diperlukan bibit ulat sutera yang mampu menghasilkan kokon yang tinggi dan berkualitas baik (Kaomini \& Andadari, 2009). Hasil penelitian dalam skala laboratorium diperoleh 4 hibrid baru hasil persilangan ras Cina dan Jepang yang mampu menghasilkan rasio kulit kokon 22-25\% (Andadari et.al., 2011), Hasil ini lebih tinggi dari bibit niagawi yang beredar di masyarakat yang baru menghasilkan ratio kulit kokon antara 20-21\% (Kaomini \& Andadari, 2009). Namun demikian, keempat hibrid tersebut baru dikembangkan di daerah dengan ketinggian tempat antara 700-800 m dpl dan belum diketahui tingkat kesesuaiannya untuk daerah dengan ketinggian di luar kondisi optimum (Andadari et al., 2013). Oleh karena itu, perlu dilakukan pengujian beberapa hibrid ulat sutera untuk mendapatkan hibrid mana yang mampu memproduksi kokon yang tinggi dan berkualitas baik untuk dibudidayakan di dataran tinggi dan/atau dataran rendah.

Penelitian bertujuan untuk mendapatkan hibrid ulat sutera yang mampu memproduksi kokon yang tinggi dan berkualitas baik untuk dikembangkan di dataran tinggi dan/atau dataran rendah. Hasil penelitian diharapkan menjadi solusi dalam peningkatan produktivitas kokon di daerah dengan kondisi lingkungan yang berbeda.

\section{METODOLOGI}

\section{A. Waktu dan Lokasi Penelitian}

Penelitian dilaksanakan pada 2 lokasi dengan kondisi lingkungan yang berbeda. Pengujian ulat di dataran tinggi dilakukan di Kecamatan Kabandungan, Kabupaten Sukabumi dengan ketinggian tempat $700 \mathrm{~m}$ dpl. Untuk dataran rendah dilakukan di Kecamatan Regaloh, Kabupaten Pati dengan ketinggian tempat 80 m dpl. Diskripsi lokasi dapat dilihat pada Tabel 1 .

\section{B. Bahan dan Alat}

Bahan yang digunakan berupa telur ulat sutera dari 4 jenis hibrid hasil persilangan Pusat Penelitian dan Pengembangan Hutan (Pusat Litbang Hutan) dan 1 hibrid hasil produksi Perum Perhutani PPUS Candiroto yaitu C301 sebagai kontrol serta daun murbei (Morus sp.) sebagai pakannya. Peralatan berupa cold strorage, inkubator, rak pemeliharaan, sasag, alat pengokonan dan lain-lain.

\section{Cara Kerja}

Teknik Pemeliharaan

- Telur diletakkan di ruang inkubasi selama 1012 hari sebelum saat penetasan dengan pengaturan suhu sekitar $25^{\circ} \mathrm{C}$ dan kelembaban 75 $80 \%$.

- Pemeliharaan ulat dilakukan di ruang pemeliharaan milik petani setempat. Ulat kecil dibungkus dengan kertas parafin sementara ulat besar diletakkan terbuka pada rak-rak pemeliharaan.

- Pemeliharaan ulat mengikuti standar yang sudah ada dengan pengaturan yang disesuai-

Tabel (Table) 1. Kondisi lokasi penelitian (Research sites condition)

\begin{tabular}{clcccc}
\hline $\begin{array}{c}\text { Kode } \\
(\text { Code })\end{array}$ & $\begin{array}{c}\text { Lokasi } \\
\text { (Site })\end{array}$ & $\begin{array}{c}\text { Ketinggian } \\
\text { tempat } \\
(\text { Altitude }) \\
(\mathrm{m} \mathrm{dpl})\end{array}$ & $\begin{array}{c}\text { Rata-rata } \\
\text { temperatur } \\
(\text { Temperature }) \\
\left({ }^{(} \mathrm{C}\right)\end{array}$ & $\begin{array}{c}\text { Rata-rata } \\
\text { kelembaban } \\
(\text { Humidity }) \\
(\%)\end{array}$ & $\begin{array}{c}\text { Curah } \\
\text { hujan/tahun/ } \\
\text { (Precipitation }) \\
(\mathrm{mm})\end{array}$ \\
\hline $\mathrm{A}$ & Regaloh-Pati & 80 & 26,9 & 78,0 & 1.387 \\
$\mathrm{~B}$ & $\begin{array}{l}\text { Kabandungan- } \\
\text { Sukabumi }\end{array}$ & 700 & 25,5 & 86,2 & 3.247 \\
\hline
\end{tabular}

Sumber (Sources): BPS Jawa Tengah (2015) dan BPS Sukabumi (2015) (BPS Central Java (2015) and BPS Sukabumi (2015) 
Tabel (Table) 2. Asal persilangan hibrid hasil dari Pusat Litbang Hutan dan Perum Perhutani (Originally cross hybrid results from the Forest $R \& D$ Centre and Perum Perhutani)

\begin{tabular}{cc}
\hline Kode hibrid (Code of hybrid) & Asal silangan (Parents) \\
\hline P3H-1 & $804 \times 102$ \\
P3H-2 & $804 \times 921$ \\
P3H-3 & $804 \times 927$ \\
P3H-4 & $932 \times 102$ \\
C301 & N1 x N2 \\
\hline
\end{tabular}

Tabel (Table) 3. Jumlah pemberian pakan (Total feeding)

\begin{tabular}{lc}
\hline Umur (Age) & $\begin{array}{c}\text { Jumlah pakan (The amount of feed) }(\mathrm{kg} / \text { instar/ulangan) } \\
\text { (kg/instar/repeats) }\end{array}$ \\
\hline Instar I & $0,12 \mathrm{~kg}$ \\
Instar II & $0,38 \mathrm{~kg}$ \\
Instar III & $1,38 \mathrm{~kg}$ \\
Instar IV & $7,00 \mathrm{~kg}$ \\
Instar V & $47,00 \mathrm{~kg}$ \\
\hline
\end{tabular}

kan dengan kondisi setempat. Kebutuhan temperatur dan kelembaban untuk masingmasing instar diupayakan agar mendekati kebutuhan optimum. Pakan diberikan sebanyak 3 kali sehari pada saat ulat kecil (instar I sampai III) dengan interval setiap 5 jam sekali mulai dari jam 07.00; 12.00 dan jam 17.00 WIB sedangkan pada saat ulat besar (instar 4 dan 5) pemberian makan dilakukan 4 kali per hari dengan interval yang sama, yaitu 5 jam (jam 07.00; $12.00 ; 17.00$ dan 22.00).

- Pada awal instar IV dihitung sebanyak 6.000 ekor ulat dari setiap plot percobaan untuk terus dipelihara dan dipertahankan sebagai obyek pengujian selanjutnya.

- Pada hari keenam sampai kedelapan dari instar V, ulat-ulat yang sudah siap memasuki masa istirahat diambil satu per satu secara manual untuk dipindahkan ke rak pengokonan.

- Kokon dipanen pada hari kelima dan keenam setelah dikokonkan dan diseleksi untuk dianalisis guna kepentingan pengukuran sesuai parameter yang diamati.

\section{Rancangan Penelitian}

Rancangan Percobaan dalam penelitian ini menggunakan Split Plot dalam Rancangan Acak Kelompok. Petak utama berupa lokasi yang berada pada dataran rendah di Kabupaten PatiJawa Tengah dan dataran tinggi di Kabupaten Sukabumi-Jawa Barat dan sebagai anak petak berupa jenis hibrid ulat sutra $(\mathrm{P} 3 \mathrm{H}-1, \mathrm{P} 3 \mathrm{H}-2$, P3H-3, P3H-4 dan C301). Pengelompokan didasarkan kepada posisi rak pemeliharaan ulat dan setiap perlakuan dikelompokkan menjadi 4 kelompok.

Setiap kelompok terdiri atas 5 induk per hibrid. Pada awal instar IV setiap plot percobaan berisi 6.000 ekor ulat. Pemeliharaaan telur hingga menjadi kokon dilakukan dengan standar pemeliharaan yang sama, meliputi tata cara inkubasi telur, penyiapan dan proses disinfeksi ruang pemeliharaan, jenis murbei dan jumlah pakan yang diberikan selama pemeliharaan ulat, pengaturan suhu dan kelembaban ruang ulat dan perlengkapan pengokonan.

Parameter yang diamati meliputi:

1. Persentase penetasan

Persentase penetasan adalah persentase telur yang menetas dari sejumlah telur dibuahi.

Persentase penetasan $(\%)=\frac{\mathrm{JTM}}{\mathrm{JTT}} \times 100 \%$

Keterangan: JTM $=$ Jumlah telur yang menetas

JTT $=$ Jumlah telur total (yang menetas dan yang tidak menetas

2. Kualitas kokon (bobot kokon, bobot kulit kokon dan rasio kulit kokon).

a. Bobot kokon segar (fresh cocoon) adalah bobot seluruh kokon yang terdiri atas kulit kokon dan pupa yang baru saja dipanen dan telah dibersihkan dari serat-serat halus pada permukaan kulit kokon (flos).

b. Bobot kulit kokon adalah bobot kulit kokon tanpa pupa. 
c. Rasio kulit kokon adalah bobot kulit kokon dibagi dengan bobot kokon dengan pupa dikalikan seratus persen.

3. Kualitas serat (panjang filamen)

Panjang filamen merupakan serat (benang) sutera yang dihasilkan dari satu butir kokon dalam satuan meter. Panjang filament, yaitu total panjang filamen dari hasil penguraian satu kokon, yang ditentukan dengan mengurai kokon dengan menggunakan alat pintal sederhana (haspel) hingga filamen dari satu buah kokon habis dan tidak dapat diurai kembali. Ujung filamen diambil lalu ditempelkan pada haspel dan dihitung jumlah putaran haspel yang menguraikan satu buah kokon, ujung filamen yang putus pada saat penguraian ditempel dengan ujung filamen yang lain dan dihitung total putaran haspel, sehingga diperoleh panjang filamen dengan rumus:

$$
\text { Panjang filamen }(\mathrm{m})=\mathrm{n} \times \mathrm{k}
$$

Keterangan: $\mathrm{n}=$ Jumlah putaran kincir

$$
\begin{aligned}
\mathrm{k}= & \text { Keliling kincir }=117 \mathrm{~cm}= \\
& 1,17 \mathrm{~m}
\end{aligned}
$$

\section{E. Analisis Data}

Untuk mengetahui ada tidaknya pengaruh interaksi, pengaruh faktor tunggal, maka data dianalisis keragaman menggunakan uji $F$. Apabila hasil analisis menunjukkan berpengaruh signifikan, selanjutnya dilakukan uji beda ratarata dengan menggunakan uji jarak berganda Tukey.

\section{HASIL DAN PEMBAHASAN}

\section{A. Hasil}

Pemilihan jenis bibit ulat sutera merupakan tahap awal yang perlu diperhatikan. Bibit ulat yang baik (unggul) akan menentukan hasil selanjutnya. Indukan yang digunakan dalam penelitian ini berasal dari hasil persilangan seperti terlihat pada Tabel 4.

Hasil persilangan tersebut, ternyata hibrid yang dihasilkan tidak selalu menghasilkan bobot kokon dan rasio kulit kokon yang lebih tinggi daripada indukan murninya. Diharapkan dari hasil persilangan bisa menghasilkan sifat-sifat unggul baik berupa kuantitas maupun kualitas kokon yang dihasilkan. Parameter-parameter kuantitas ditentukan oleh persentase penetasan, bobot kokon, bobot kulit kokon dan rasio kulit kokon sedangkan kualitas kokon ditentukan oleh panjang filamen.

Penetapan produktivitas ulat sutera ditentukan oleh tingginya persentase penetasan, bobot kokon, bobot kulit kokon dan rasio kulit kokon. Faktor-faktor ini penting untuk diketahui para pemintal, karena biaya produksi benang berhubungan langsung dengan harga yang akan dibayarkan. Hasil analisis ragam menunjukkan bahwa faktor lokasi, jenis hibrid serta interaksi keduanya tidak berpengaruh signifikan terhadap persentase penetasan. Hasil analisis ragam menunjukkan bahwa terhadap bobot kokon dan bobot kulit kokon tidak terjadi interaksi yang nyata. Faktor tunggal lokasi dan jenis hibrid

Tabel (Table) 4. Bobot kokon dan rasio kulit kokon dari indukan dan hasil persilangannya (The cocoon weight and the cocoon shell of hybrids and its parents)

\begin{tabular}{lcc}
\hline \multicolumn{1}{c}{ Indukan (Parent) } & $\begin{array}{c}\text { Bobot kokon (The Cocoon weight) } \\
(\mathrm{g})\end{array}$ & $\begin{array}{c}\text { Rasio kulit kokon (The cocoon shell ratio) } \\
(\%)\end{array}$ \\
\hline P3H-1 (804 x 102) & 1,55 & 20,38 \\
804 & 1,92 & 22,58 \\
102 & 1,53 & 15,29 \\
P3H-2 (804 x 921) & 1.64 & 21,01 \\
804 & 1,92 & 22,58 \\
921 & 1,91 & 21,57 \\
P3H-3 (804 x 927) & 1,61 & 20,86 \\
804 & 1,92 & 22,58 \\
927 & 2,00 & 22,50 \\
P3H-4 (932 x 102) & 1,53 & 20,20 \\
932 & 1,92 & 21,36 \\
102 & 1,32 & 15,29 \\
C301 (102 x 202) & 1,27 & 18,70 \\
102 & 1,32 & 15,29 \\
202 & 1,25 & 14,54 \\
\hline
\end{tabular}

Sumber (Sources) : Data primer hasil penelitian (Primary data research result) 
berpengaruh signifikan terhadap bobot kokon, namun terhadap bobot kulit kokon hanya faktor jenis hibrid yang berpengaruh sangat nyata. Tabel 5 menunjukkan bahwa lokasi dataran tinggi di Kabupaten Sukabumi menghasilkan bobot kokon lebih tinggi daripada lokasi dataran rendah di Kabupaten Pati. Namun terhadap bobot kulit kokon telah menghasilkan bobot kulit kokon yang sama untuk 2 lokasi tersebut. Jika dilihat dari faktor tunggal jenis hibrid, maka ulat sutera yang telah menghasilkan bobot kokon yang baik adalah hibrid $\mathrm{P} 3 \mathrm{H}-1, \mathrm{P} 3 \mathrm{H}-2$ dan $\mathrm{P} 3 \mathrm{H}-3$ sedangkan yang menghasilkan bobot kulit kokon yang tinggi adalah $\mathrm{P} 3 \mathrm{H}-2, \mathrm{P} 3 \mathrm{H}-3$ dan $\mathrm{P} 3 \mathrm{H}-4$.
Pada Tabel 6 terlihat bahwa keempat hibrid hasil Pusat Litbang Hutan yang dibudidayakan di dataran rendah Kabupaten Pati menghasilkan rasio kulit kokon yang sama baiknya, tetapi terhadap hibrid C301 (dari Perum Perhutani PPUS Candiroto) berbeda signifikan dan rasio kulit kokonnya jauh lebih tinggi daripada hibrid C301. Jika dikembangkan di dataran tinggi, maka hibrid $\mathrm{P} 3 \mathrm{H}-2$ dan $\mathrm{P} 3 \mathrm{H}-3$ menghasilkan rasio kulit kokon terbaik dan berbeda signifikan dengan hibrid P3H-1, P3H-4 dan C301. Jika dibudidayakan di dataran rendah dan dataran tinggi, maka hibrid $\mathrm{P} 3 \mathrm{H}-2$ menghasilkan rasio kulit kokon yang tertinggi.

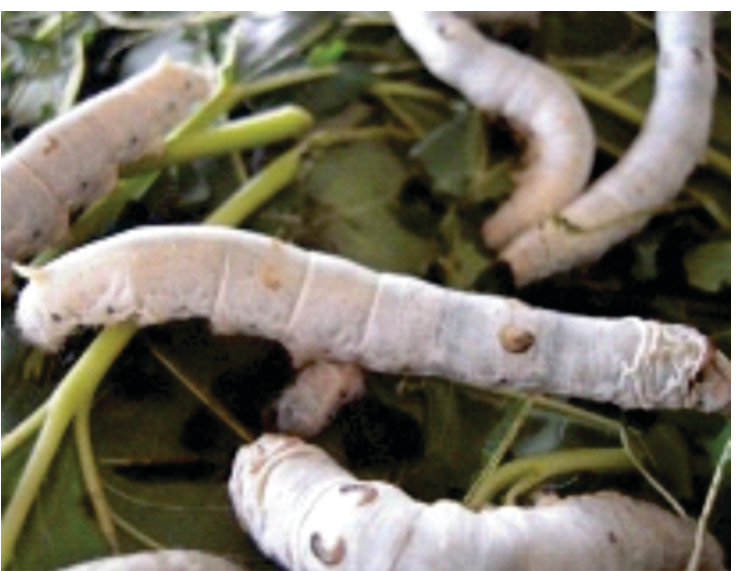

Hibrid P3H 2

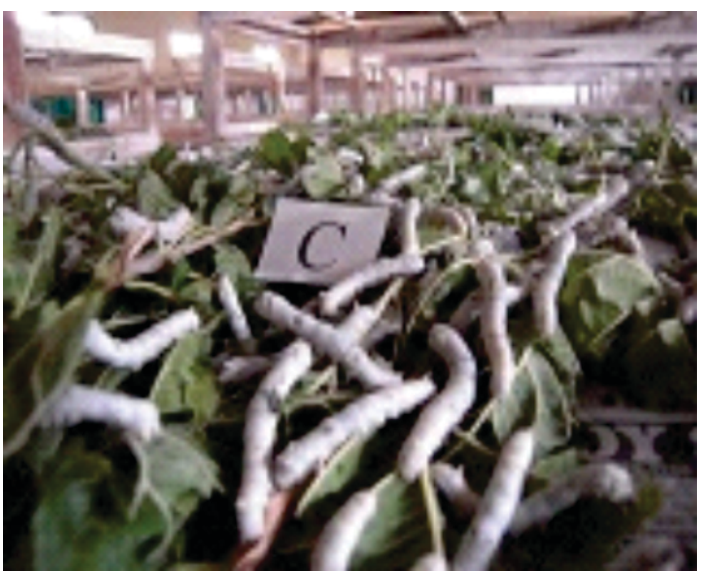

Hibrid C301

Gambar(Figure) 1. Hibrid P3H-2 dan C301 yang diujikan di Sukabumi dan Pati (P3H-2 and C3O1 hybrids tested in Sukabumi and Pati)

Tabel (Table) 5. Rata-rata bobot kokon dan bobot kulit kokon pada 2 lokasi dan 5 jenis hibrid (The average weight of the cocoon and cocoon shell weight at two locations and five types of hybrid)

\begin{tabular}{|c|c|c|c|}
\hline Perlakuan (Treatment) & $\begin{array}{c}\text { Penetasan } \\
\text { (Hatchability) } \\
(\%)\end{array}$ & $\begin{array}{c}\text { Bobot kokon } \\
\text { (Cocoon weight) } \\
(\mathrm{g})\end{array}$ & $\begin{array}{c}\text { Bobot kulit kokon } \\
\text { (Shell cocoon weight) } \\
(\mathrm{g})\end{array}$ \\
\hline \multicolumn{4}{|l|}{ Lokasi (Location) } \\
\hline Pati & $96,90^{\mathrm{a}}$ & $1,33 \mathrm{~b}$ & $0,28^{a}$ \\
\hline Sukabumi & $96,66^{\mathrm{a}}$ & 1,71 a & $0,28^{a}$ \\
\hline \multicolumn{4}{|l|}{ Jenis hybrid (Hybride kinds) } \\
\hline $\mathrm{P} 3 \mathrm{H}-1$ & $97,27 \mathrm{a}$ & $1,54 \mathrm{ab}$ & $0,29 \mathrm{~b}$ \\
\hline P3H-2 & $97,06^{\mathrm{a}}$ & $1,66^{\mathrm{a}}$ & 0,32 a \\
\hline $\mathrm{P} 3 \mathrm{H}-3$ & $97,00^{\mathrm{a}}$ & $1,60 \mathrm{ab}$ & $0,29 \mathrm{ab}$ \\
\hline P3H-4 & $96,57 \mathrm{a}$ & $1,52 \mathrm{~b}$ & $0,30 \mathrm{ab}$ \\
\hline Perhutani C301 & 96,01 a & $1,27 \mathrm{c}$ & $0,20^{\mathrm{c}}$ \\
\hline
\end{tabular}

Keterangan (Remarks): Nilai dalam kolom yang diikuti dengan huruf yang sama berarti tidak berbeda nyata 5\% berdasarkan Uji Tukey pada taraf nyata 5\% (Figures on the same column bearing same letter denote non significant differences at $5 \%$ level according to Tukey test) 
Tabel(Table) 6. Interaksi antara lokasi dan jenis hibrid terhadap rasio kulit kokon (The interaction between the location and the type of hybrid on the cocoon shell ratio)

\begin{tabular}{lrrrrrr}
\hline & \multicolumn{5}{c}{ Jenis hybrid (Hybride kinds) } & \multicolumn{5}{c}{ Rasio kulit kokon (The cocoon shell ratio) (\%) } \\
\cline { 3 - 7 } Lokasi (Location) & P3H-1 & P3H-2 & P3H-3 & P3H-4 & C301 \\
\hline Pati & $21,53 \mathrm{a}$ & 21,48 a & 21,36 ab & 21,47 a & $19,54 \mathrm{~cd}$ \\
Sukabumi & $19,22 \mathrm{~d}$ & 20,54 abc & $20,35 \mathrm{bc}$ & $19,00 \mathrm{~d}$ & 17,90 e \\
\hline
\end{tabular}

Keterangan (Remarks): Nilai dalam kolom yang diikuti dengan huruf yang sama berarti tidak berbeda nyata $5 \%$ berdasarkan Uji Tukey pada taraf nyata 5\% (Figures on the same column bearing same letter denote non significant differences at $5 \%$ level according to Tukey test)

Pada Tabel 7 menunjukkan bahwa hibrid ulat sutera $\mathrm{P} 3 \mathrm{H}-1, \mathrm{P} 3 \mathrm{H}-2$ dan $\mathrm{P} 3 \mathrm{H}-4$ yang dibudidayakan di dataran rendah telah menghasilkan panjang filamen yang sama dan lebih panjang daripada hibrid lainnya. Namun, apabila dibudidayakan di dataran tinggi, maka dapat dipilih hibrid $\mathrm{P} 3 \mathrm{H}-1, \mathrm{P} 3 \mathrm{H}-2$ dan $\mathrm{P} 3 \mathrm{H}-3$. Jika dibudidayakan di dataran rendah dan dataran tinggi, maka hibrid $\mathrm{P} 3 \mathrm{H}-1$ dan $\mathrm{P} 3 \mathrm{H}-2$ yang menghasilkan panjang filamen yang terbaik.

\section{B. Pembahasan}

Keseragaman penetasan dan persentase penetasan yang tinggi merupakan hal yang sangat utama dalam usaha budidaya ulat sutera (Andadari \& Kuntadi, 2014). Kedua parameter ini sering dijadikan tolok ukur kualitas bibit, meskipun keberhasilannya akan dicapai jika didukung oleh sistem penetasan dan penanganan telur yang sesuai dengan ketentuan. Pada penelitian ini semua penanganan telur adalah sama untuk setiap perlakuan hibrid. Hasil penelitian menunjukkan bahwa persentase penetasan seragam, untuk semua perlakuan dengan tingkat penetasan yang tinggi rata-rata di atas $96 \%$.

Persentase penetasan kelima hibrid (Pusat Litbang Hutan dan Perum Perhutani) menunjukkan persentase penetasan yang sama tinggi karena semua jenis hibrid mendapat perlakuan inkubasi yang sama. Inkubasi telur adalah penyimpanan telur di dalam ruangan dengan pengaturan temperatur, kelembaban dan cahaya yang sama untuk semua tempat. Tujuan inkubasi, yaitu agar telur dapat ditetaskan dengan baik dan merata selama 10 hari. Kebutuhan temperatur selama inkubasi adalah $25^{\circ} \mathrm{C}$ dan kelembaban 75$80 \%$ dengan pengaturan cahaya 18 jam terang dan 6 jam gelap setiap harinya sesuai dengan standar inkubasi menurut Hussain et al. (2011b). Oleh karena itu, persentase penetasan tidak dipengaruhi oleh jenis hibrid dan lokasi.

Bobot kokon merupakan salah satu parameter penting yang harus diketahui pada setiap hasil pemeliharaan ulat sutera karena akan berpengaruh terhadap serat dan benang yang dihasilkan (Nurhaedah et al., 2006). Bobot kokon mempunyai korelasi positif dengan hasil kokon per boksnya. Berdasarkan hasil penelitian ada perbedaan yang nyata pada bobot kokon antar lokasi, pemeliharaan yang dilakukan di dataran tinggi di Kabupaten Sukabumi pada ketinggian $700 \mathrm{~m}$ dpl, menghasilkan rata-rata bobot kokon yang tinggi $(1,71 \mathrm{~g})$. Ulat sutera merupakan serangga berdarah dingin (poikilothermic) yang mudah dipengaruhi oleh kondisi lingkungan, dengan demikian pada kondisi yang optimum pertumbuhan ulat lebih baik dan menghasilkan kokon yang optimum (Nursita, 2011; Hussain et al., 2011a). Sebaliknya pada kondisi minimum seperti halnya di daerah Pati pada ketinggian

Tabel(Table) 7. Interaksi antara lokasi dan jenis hibrid terhadap panjang filamen (The interaction between locations and hybrids to the length of filament)

\begin{tabular}{lccccc}
\hline & Jenis hibrid (Hybride kinds) & \multicolumn{5}{c}{ Panjang filament (Filament length) (m) } \\
\cline { 2 - 6 } Lokasi (Location) & P3H-1 & P3H-2 & P3H-3 & P3H-4 & C 301 \\
\hline Pati & $1.065,40$ abc & $1.066,40 \mathrm{abc}$ & $1.003,67 \mathrm{bcd}$ & $1.126,00 \mathrm{ab}$ & $755,67 \mathrm{e}$ \\
Sukabumi & $1.066,67 \mathrm{abc}$ & $1.100,00 \mathrm{abc}$ & $1.160,00 \mathrm{a}$ & $950,00 \mathrm{~cd}$ & $883,33 \mathrm{de}$ \\
\hline
\end{tabular}

Keterangan (Remarks): Nilai dalam kolom yang diikuti dengan huruf yang sama berarti tidak berbeda nyata 5\% berdasarkan Uji Tukey pada taraf nyata 5\% (Figures on the same column bearing same letter denote non significant differences at 5\% level according to Tukey test) 
$80 \mathrm{~m}$ dpl, kokon yang dihasilkan menjadi lebih rendah, rata-rata berkisar 1,41 g. Hal ini disebabkan di daerah Pati dengan suhu tinggi dan kelembaban rendah dapat menyebabkan daun murbei yang diberikan cepat mengalami kekeringan, sehingga palatabilitasnya menurun. Namun demikian keempat hibrid Pusat Litbang Hutan konsisten menghasilkan bobot kokon lebih tinggi dibandingkan yang dihasilkan oleh hibrid Perum Perhutani PPUS Candiroto yaitu C301 baik yang dipelihara di dataran tinggi maupun di dataran rendah.

Pada penelitian ini, hibrid $\mathrm{P} 3 \mathrm{H}-2$ menghasilkan bobot kokon yang tertinggi (1,66 g) sedangkan hibrid C301 menghasilkan bobot kokon terendah $(1,27 \mathrm{~g})$. Secara umum, kokon dari hibrid hasil persilangan Pusat Litbang Hutan memiliki bobot di atas $1,50 \mathrm{~g}$ dan berbeda sangat nyata dibanding kokon hasil produksi hibrid C301. Disimpulkan bahwa hibrid $\mathrm{P} 3 \mathrm{H}-2$ potensial untuk dikembangkan baik pada ketinggian yang tinggi maupun pada daerah yang rendah (80-700 m dpl).

Menurut Kaomini \& Andadari (2009) bobot kokon mempunyai korelasi positif dengan hasil kokon per boks dan berhubungan erat dengan nilai tambah yang diperoleh petani sutera. Sehubungan dengan hal tersebut, maka dari segi produksi kokon maupun nilai tambah yang diperoleh petani sutera hibrid ulat sutera Pusat Litbang Hutan dapat dianjurkan untuk dikembangkan.

Tabel 7 menunjukkan variasi peningkatan dan penurunan bobot kokon dan rasio kulit kokon dari kelima hibrid dibandingkan dengan indukannya. Variasi tersebut disebabkan karena indukan yang terlibat dalam persilangan sudah memiliki rasio kulit kokon yang tinggi akibat seleksi secara terus menerus dan karena selisih nilai rasio kulit kokon antara indukannya sangat kecil. Dengan demikian, peningkatan yang terjadi sangat kecil atau tidak terjadi sama sekali atau dapat pula disebabkan oleh daya gabung yang kurang baik antara kedua tetuanya (Endarwati et al., 2006). Adanya variasi dapat juga disebabkan oleh pengaruh lingkungan, dimana lokasi yang berlainan membuat jenis hibrid memberikan respon yang tidak sama (Gowda \& Reddy, 2007; Seidavi, 2012). Walaupun keempat hibrid Pusat Litbang Hutan terdapat penurunan dari indukannya, namun hasilnya lebih tinggi daripada hibrid C301.

Bobot kulit kokon berhubungan dengan kandungan sutera yang dapat dimanfaatkan, semakin besar bobot kulit kokon, maka semakin besar kandungan benang sutera (Andadari et al., 2013; Nuraeni \& Baharudin, 2009). Bobot kulit kokon keempat hibrid Pusat Litbang Hutan menunjukkan hasil yang signifikan dibandingkan dengan hibrid C301. Rata-rata bobot kulit kokon keempat hibrid Pusat Litbang Hutan meningkat sebesar 50\% dari hibrid C301. Pada dataran rendah di Kabupaten Pati keempat hibrid menunjukkan hasil yang sama, yang berarti keempat hibrid tersebut mampu beradaptasi pada dataran rendah. Namun, di dataran tinggi di Kabupaten Sukabumi menghasilkan bobot kulit kokon yang berbeda. Jenis hibrid P3H-1 dan P3H-2 menghasilkan bobot kulit kokon tinggi. Hal ini menunjukkan bahwa jenis hibrid mempengaruhi bobot kulit kokon. Kumar et al. (2011) mengemukakan bahwa bobot kulit kokon ditentukan oleh ras, galur, jenis kelamin ulat yang dipelihara, kondisi pemeliharaan dan pengokonan.

Pada kondisi optimum walaupun kempat hibrid Pusat Litbang Hutan menghasilkan rasio kulit kokon lebih tinggi dari hibrid Perum Perhutani, hanya hibrid P3H-2 dan P3H-3 yang konsisten menghasilkan rasio kulit kokon tinggi. Persentase kulit kokon hibrid di daerah tropis menurut Andadari et al. (2013) berkisar antara $18,0-22,0 \%$. Keempat hibrid Pusat Litbang Hutan telah menghasilkan rata-rata rasio kulit kokon antara 21,36-21,53\% dan termasuk kelas B sedangkan hibrid C301 menghasilkan rasio kulit kokon 19,64\% dan tergolong kelas C. Rasio kulit kokon keempat hibrid Pusat Litbang Hutan yang dipelihara di dataran rendah lebih tinggi daripada yang dipelihara di dataran tinggi. Diduga penyebabnya adalah perbedaan kemampuan daya tahan terhadap kondisi lingkungan dengan suhu tinggi dan kelembaban rendah dan perbedaan kemampuan kelenjar sutera dalam menghasilkan benang. Ulat sutera yang lebih tahan terhadap kondisi lingkungan dengan suhu tinggi dan kelembaban rendah akan berproduksi lebih baik (Nursita, 2011; Kumar \& Singh, 2012)

Ada korelasi positif antara rasio kulit kokon dengan panjang filamen, semakin besar rasio kulit kokon, maka filamen yang dihasilkan akan semakin panjang. Keempat hibrid Pusat Litbang Hutan sudah memenuhi persyaratan panjang filamen normal dan memenuhi nilai komersil dengan nilai kisaran antara 1.004-1.126 m. Hasil ini lebih tinggi dari hibrid impor yang berkisar 800-1.000 m. Kualitas serat dipengaruhi oleh kualitas kokon yang dipintal (Kumar et al., 2014). Muin et al. (2015) menyatakan semakin panjang serat, maka mutunya semakin baik. 
Panjang filamen yang baik (normal) berkisar 800-1.500 m. Panjang filamen keempat hibrid Pusat Litbang Hutan tersebut lebih tinggi dari pada panjang filamen hibrid import Cina hasil penelitian yaitu berkisar 800-900 m (Andadari \& Kuntadi, 2014).

Pemeliharaan ulat dengan menggunakan hibrid Pusat Litbang Hutan dibandingkan hibrid C301 terdapat peningkatan produksi kokon sebesar 32\% untuk dataran tinggi (kondisi optimum) dan 18,92\% untuk dataran rendah (kondisi minimum). Jika dibandingkan dengan bibit impor Cina untuk dataran rendah hanya menghasilkan kenaikan produksi kokon sebesar $12 \%$, untuk kondisi optimum pemeliharaan ulat dengan hibrid Pusat Litbang Hutan dibandingkan dengan bibit import Cina produksi kokon meningkat $10 \%$.

Kualitas kokon dan panjang filamen keempat hibrid Pusat Litbang Hutan menunjukkan hasil yang sama pada dataran rendah hal ini dikarenakan keempat hibrid Pusat Litbang Hutan menggunakan galur yang produktivitasnya tertinggi dari koleksi ulat sutera yang dimiliki oleh Pusat Litbang Hutan. Koleksi ulat sutera tersebut berada di ketinggian $200 \mathrm{~m}$ dpl. Hasil penelitian dalam skala laboratorium menunjukkan bahwa 4 hibrid tersebut menghasilkan rasio kulit kokon $22-25 \%$, sementara bibit C301 yang beredar di Indonesia hanya mencapai $20-21 \%$. Namun, keempat hibrid tersebut setelah diujikan skala lapangan dengan kondisi lingkungan berlainan telah menghasilkan rasio kulit kokon menurun sekitar 19-21\%. Hal ini disebabkan pertumbuhan ulat sutera sangat dipengaruhi oleh kondisi tempat pemeliharaannya, karena ulat sutera termasuk binatang berdarah dingin.

Berdasarkan data yang diperoleh di 2 kondisi yang berbeda ternyata hibrid Pusat Litbang Hutan menghasilkan kualitas kokon dan panjang filamen lebih tinggi daripada hibrid C301. Ratarata panjang filamen keempat hibrid Pusat Litbang Hutan lebih panjang daripada hibrid C301. Peningkatan panjang filamen dari keempat hibrid Pusat Litbang Hutan sebesar $41 \%$ untuk dataran rendah sedangkan untuk dataran tinggi panjang filamen terdapat peningkatan sebesar $21 \%$. Hal ini menunjukkan keempat hibrid Pusat Litbang Hutan adaptif untuk dikembangkan di kedua lokasi tersebut. Di dataran tinggi di Kabupaten Sukabumi, keempat hibrid menunjukkan hasil yang berbeda. P3H-2 dan P3H-3 konsisten memberikan hasil panjang filamen yang sama antara dataran tinggi dan rendah. $\mathrm{P} 3 \mathrm{H}-2$ dan
P3H-3 mampu adatif di kedua lokasi, namun cenderung hasilnya lebih baik di dataran tinggi.

Panjang filamen keempat hibrid Pusat Litbang Hutan hasil penelitian ini ternyata lebih panjang daripada hibrid impor dari Cina. Menurut Andadari \& Kuntadi (2014) hibrid asal Cina pada pemeliharaan di Soppeng (kondisi minimum dengan ketinggian $100 \mathrm{~m} \mathrm{dpl}$ ) hanya mampu menghasilkan rata-rata panjang filamen rata-rata $900 \mathrm{~m}$. Keempat hibrid Pusat Litbang Hutan pada pemeliharaan di dataran rendah dapat menghasilkan panjang filamen rata-rata $1.000 \mathrm{~m}$.

Hasil pengamatan secara umum terhadap kualitas kokon dan serat, meliputi persentase penetasan. bobot kokon, bobot kulit kokon, ratio kulit kokon dan panjang serat dari ulat sutera yang dipelihara di 2 kondisi yang berbeda menunjukkan nilai yang lebih tinggi dibanding kontrol C301. Hal ini menunjukkan bahwa tingkat kecocokan hibrid Pusat Litbang Hutan mampu beradaptasi baik di dataran tinggi maupun dataran rendah.

\section{KESIMPULAN DAN SARAN}

\section{A. Kesimpulan}

Tingkat penetasan ulat sutera tidak dipengaruhi oleh jenis hibrid maupun lokasi pemeliharaan. Keseluruhan bibit ulat yang diuji menghasilkan persentase penetasan yang tinggi ( $>96 \%$ ) di 2 lokasi penelitian. Ulat sutera potensial untuk dibudidayakan di dataran rendah di dataran rendah adalah $\mathrm{P} 3 \mathrm{H}-1, \mathrm{P} 3 \mathrm{H}-2$ dan $\mathrm{P} 3 \mathrm{H}-4$. Hibrid $\mathrm{P} 3 \mathrm{H}-2$ dan $\mathrm{P} 3 \mathrm{H}-3$ cocok dibudidayakan di dataran tinggi. Hibrid $\mathrm{P} 3 \mathrm{H}-2$ potensial untuk dikembangkan dataran rendah dan di dataran tinggi.

\section{B. Saran}

Sebelum dikembangkan lebih luas, maka keempat hibrid Pusat Litbang Hutan perlu diuji pada kondisi agroklimat dan musim yang berbeda.

\section{UCAPAN TERIMA KASIH}

Ucapan terima kasih disampaikan kepada teknisi-teknisi Laboratorium Persutraan Alam: Tri Rahmawati, Heman Sari dan Heri Kurniawan yang telah membantu penelitian ini. 


\section{DAFTAR PUSTAKA}

Andadari, L., Pudjiono. S., Suwandi \& Rahmawati, T. (2013). Budidaya murbei dan ulat sutera. FORDA PRESS. ISBN: 978-602-14274-6-0.

Andadari \& Kuntadi. (2014). Perbandingan hibrid ulat sutera (Bombyx mori L.) asal Cina dengan hibrid lokal di Sulawesi Selatan. Jurnal Penelitian Hutan Tanaman, 11(3), 173-183.

Andadari, L., Rahmawati, T. \& Suwandi. (2011). Pengembangan koleksi ulat sutera. (tidak dipublikasikan). Laporan Hasil Penelitian. Pusat Penelitian dan Pengembangan Hutan dan Konservasi Alam. Bogor.

BPS Jawa Tengah Dalam Angka (2015). Bidang integrasi pengolahan dan deseminasi statistik. Akses tanggal 26 Mei 2016.

BPS Kabupaten Sukabumi. (2013). Kabupaten Sukabumi dalam angka 2013. Akses tanggal 26 Mei dari:https://www.scribd.com/doc/ 257481114 Sukabumi-Dalam-Angka-2013.

Endarwati. Y.C., Siregar, H.C.H. \& Kaomini, M. (2006). Kajian pengaruh bobot kokon induk terhadap kualitas telur persilangan ulat sutera (Bombyx mori L.) Ras cina dengan ras Jepang. Jurnal Peternakan Indonesia, 2(2), 173-180.

Gowda, B.N. \& Reddy, N.M. (2007). Influence of different environmental conditions on cocoon parameters and their effects for reeling performance of bivoltine hybrids of silkworm, Bombyx mori L. Int. J. Indust. Entomol, 14(1), 15-21.

Hussain, M., Naeem. M., Khan, S.A., Bhatti, M.F. \& Munawar, M. (2011a). Studies on the enfluance of temperature and humidity on biological traits of silkworm (Bombyx mori L. : Bombycidae). African J. Biotech, 10(57), 12368-12375.

Hussain, M., Khan. S.A., Naeem, M., Aqil, T., Khursheed, R. \& Ul Mohsin, A. (2011b). Evaluations of silkworm lines against variations in temperature and $\mathrm{RH}$ for various parameters of commercial cocoon production. Psyche vol. 2011, article ID 145640. http://www.hindawi.com/journals/psyche/ 2011/145640/. Diakses 5 Mei 2016.

Kaomini, M., \& Andadari, L. (2009). Sintesis Hasil Penelitian Teknologi Peningkatan Produktivitas dan kualitas Produk Ulat sutera. Pusat Penelitian dan Pengembangan Hutan dan Konservasi Alam. Tidak diterbitkan.
Kumar, V., Kumar, D. \& Ram, P. (2014). Varietal influence of mulberry on silkworm, Bombyx mori L. growth and development. Research Article. International Journal of Advanced Research, 2(3), 921-927.

Kumar, S.N. \& Singh, H. (2012). Evaluation of the reproductive potential of bivoltine silkworm hybrids of Bombyx Mori L under high temperature and high humidity and high temperature and low humidity conditions of the tropics. Universal Journal of Environmental Research and Technology. eISSN 2249 0256, 2(5), 443449.

Kumar, S,N., Singh, H., Saha, A.K. \& Bindroo, B.B. (2011). Development of bivoltine double hybrid of the silkworm, Bombyx Mori L. tolerant to high temperature and high humidity conditions of the tropics. Universal Journal of Environmental Research and Technology. eISSN 2249 0256, 1(4), 423-434.

Muin, Suryanto, N. \& Minarningsih. (2015). Uji coba hibrid Morus khunpai dan M. indica sebagai pakan ulat sutera ( Bombyx mori Linn.). Jurnal Penelitian Kehutanan Wallacea, 4(2), 137145.

Nursita, I,W. (2011). Perbandingan produktivitas ulat Sutera dari dua tempat pembibitan yang berbeda pada kondisi lingkungan pemeliharaan panas. Jurnal Ilmu-ilmu Peternakan, 21(3), 10-17.

Nuraeni, S., \& Baharudin. (2009). Perbandingan karakteristik dan produktivitas ulat sutera (Bombyx mori L.) dari dua sumber bibit di Sulawesi Selatan. Jurnal Perennial, 6(1), 3943.

Nurhaedah, Budi Santoso, H. \& Isnan, W. (2006). Pengaruh murbei (Morus spp.) dan ulat sutera persilangan (Bombyx mory Linn.) terhadap kualitas ulat, kokon dan serat sutera. Jurnal Penelitian Hutan dan Konservasi Alam, 3(1), 65-73.

Santoso, B. (2012). Murbei varietas NI (varietas unggul). Jurnal Penelitian Kehutanan Wallacea, 1(2).

Seidavi, A. (2012). Study on thirty-one economically important traits in twenty silkworm Bombyx mori varieties. African J. Biotechnology, 11(36), 8938-8947. 



\title{
PERBEDAAN KOMPOSISI HUTAN ALAM PRODUKSI PADA BERBAGAI UMUR BEKAS TEBANGAN DAN LERENG
}

\author{
The Composition Differenciate of Natural Forest Production at Some Time \\ Cutting and Slope Class
}

\author{
Lutfy Abdulah dan/and Mira Yulianti \\ Pusat Penelitian dan Pengembangan Hutan \\ Kampus Badan Litbang dan Inovasi, Jl. Gunung Batu No. 5 Kotak Pos 165 Bogor 16118, Jawa Barat, Indonesia \\ Tlp. : (0251) 8633234; Fax. : (0251) 8638111 \\ Email: lutfyabdulah@yahoo.co.id; mitra_solvay@yahoo.com
}

Tanggal diterima: 10 Juli 2014; Tanggal direvisi: 2 Mei 2016; Tanggal direvisi: 6 Juni 2016

\begin{abstract}
The management of natural forests production in Indonesia have been facing with the pressure to sustainability of growth and results. Number of tree and number of tree species have been dimishing after harvested for long time. That is effect to reduction of forest production value. The objective of the research was to determine the impact of logging on biodiversity and to calculate natural regeneration. The research method by transect survey on logged area at 2002, 2003, 2012 and 2013. Parameters consisted of individual density, frequency, dominance, species richness, diversity, and level of slope. The result showed that there are 5 types of commercially namely $\underline{\mathrm{S}}$. $\underline{\mathrm{selanica}} B I$,

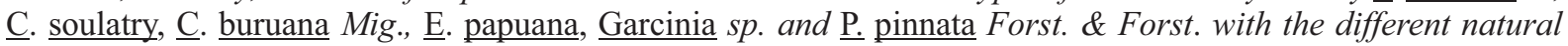
regeneration condition. The IVI of commercial species still good by dominanted by non commercial species. The richness index is moderate and diversity index is low. It is need to improve by silviculture treathment and biophysical consideration by development a plantation area in unproductive area with commercial species.
\end{abstract}

Keywords: Diversity, important value, log over area, species richness

\begin{abstract}
ABSTRAK
Pengelolaan hutan alam produksi di Indonesia dihadapkan pada tekanan kelestarian pertumbuhan dan hasil. Jenisjenis yang ditebang pada rotasi berikutnya mengalami penurunan baik potensi maupun permudaannya dan jenisjenis non komersial akan dominansi di areal bekas tebangan. Tujuan penelitian adalah mengetahui dampak penebangan terhadap biodiversitas dan proyeksi permudaan alami. Metode yang digunakan adalah metode analisis vegetasi di LOA tahun 2002, 2003, 2012 dan 2013 dengan parameter kerapatan individu, frekuensi, dominansi pada berbagai level pertumbuhan, kekayaan jenis, keragaman jenis dan pengaruh kelerengan terhadap potensi tegakan tinggal dan permudaan alami. Hasil penelitian menunjukkan terdapat 5 jenis komersial yaitu $S$. selanica BI, C. soulatry Burm., C. buruana Mig., E. papuana dan P. pinnata Forst. \& Forst.. INP jenis komersil masih dikatakan baik meski jenis non komersil masih mendominasi LOA. Indeks kekayaan jenis dapat dikatakan baik namun indeks keragaman jenis tergolong rendah. Untuk itu perlu adanya perbaikan silvikultur dengan mempertimbangkan aspek biofisik melalui penanaman lahan tidak produktif dengan jenis-jenis komersil.
\end{abstract}

Kata kunci: Hutan bekas tebangan, kekayaan jenis, keragaman, nilai penting

\section{PENDAHULUAN}

Pengelolaan hutan alam produksi di Indonesia dihadapkan pada tekanan kelestarian pertumbuhan dan hasil, konservasi sumberdaya hutan serta bentuk-bentuk tekanan sosial dan ekonomi baik itu dari usaha sejenis maupun dari usaha sektor non kehutanan seperti pertambangan dan perkebunan. Salah satu penyebab tekanan adalah laju pertumbuhan hutan bekas tebangan (log over area, LOA) yang sangat lambat dan tidak seiring dengan laju penebangan atau permintaan kayu bulat di pasar. Pertumbuhan LOA yang lambat disebabkan oleh perubahan pada struktur dan komposisi tegakan alam (Muhdi et al., 2009).

PT. Gema Hutani Lestari merupakan salah satu unit manajemen pemanfaatan hasil hutan kayu di Pulau Buru - Maluku seluas 148.450 ha dan potensi tegakan mencapai $4.430 .340 \mathrm{~m}^{3}$ dan sesuai Keputusan Menteri Kehutanan dan 